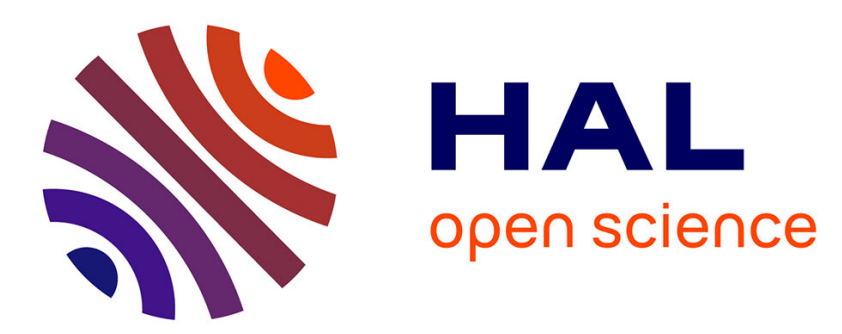

\title{
Statistical physics modelling of azo dyes biosorption onto modified powder of Acorus calamus in batch reactor
}

Chaker Djama, Derradji Chebli, Abdallah Bouguettoucha, Ilyas Doudou, Abdeltif Amrane

\section{- To cite this version:}

Chaker Djama, Derradji Chebli, Abdallah Bouguettoucha, Ilyas Doudou, Abdeltif Amrane. Statistical physics modelling of azo dyes biosorption onto modified powder of Acorus calamus in batch reactor. Biomass Conversion and Biorefinery, 2023, 13, pp.1013-1028. 10.1007/s13399-020-01190-2 . hal03127403

\section{HAL Id: hal-03127403 \\ https://hal.science/hal-03127403}

Submitted on 22 Feb 2021

HAL is a multi-disciplinary open access archive for the deposit and dissemination of scientific research documents, whether they are published or not. The documents may come from teaching and research institutions in France or abroad, or from public or private research centers.
L'archive ouverte pluridisciplinaire HAL, est destinée au dépôt et à la diffusion de documents scientifiques de niveau recherche, publiés ou non, émanant des établissements d'enseignement et de recherche français ou étrangers, des laboratoires publics ou privés. 


\title{
Statistical physics modelling of azo dyes biosorption onto modified powder of Acorus calamus in batch reactor
}

\author{
Chaker DJAMA ${ }^{\mathrm{a}^{*}}$, Derradji CHEBLI ${ }^{\mathrm{a}}$, Abdallah BOUGUETTOUCHA ${ }^{\mathrm{a}}$, Ilyas DOUDOU ${ }^{\mathrm{a}}$
}

\begin{abstract}
Abdelif AMRANE ${ }^{\mathrm{b}}$
åLaboratoire de Génie des Procédés Chimiques, Faculté de Technologie, Département de Génie des Procédés, Université Ferhat Abbas, Sétif-1, El Bez, 19000 Sétif, Algérie, Tel./Fax: +213 36

9251 21; emails; chaker.djama@univ-setif.dz; abdallah.bouguettoucha@univ-setif.dz; derradji.chebli@univ-setif.dz; ilyas.doudou@univ-setif.dz

bUniv Rennes, Ecole Nationale Supérieure de Chimie de Rennes, CNRS, ISCR-UMR 6226, F-35000 Rennes, email: abdeltif.amrane@univ-rennes1.fr
\end{abstract}

\begin{abstract}
The methylene blue adsorption was carried out on a natural material powder of Acorus calamus treated firstly with $\mathrm{H}_{2} \mathrm{SO}_{4}$ and then activated by $\mathrm{KMnO}_{4}$. The new material was called PACK. Fourier transform infrared FTIR spectroscopy, pHpzc analysis and SEM micrograph were carried out to characterize the material. Pseudo-first-order, pseudo-second-order and pseudo-n ${ }^{\text {th }}$ order constant rates were calculated for analysis of the dynamics of the sorption process, showing that sorption kinetics followed a pseudo-n ${ }^{\text {th }}$ order model. Among the tested isotherm models, the R-P isotherm was considered to be the most relevant to describe MB sorption onto PACK. Advanced statistical physic models, Monolayer single-energy, monolayer two-energy, and double-layer twoenergy were used to analyze the adsorption mechanism of methylene blue (MB) and to understand the PACK adsorbent performance. Based on the $\mathrm{R}^{2}$ values obtained, the monolayer two-energy
\end{abstract}


model was found to be the most suitable to describe the MB adsorption onto the PACK material. From this, the adsorption of MB was assumed on two different sites of PACK with two different energies, E1 for the first site and E2 for the second site. These two different receptor sites can interact with a variable number of MB molecules (n), n1 with the first type of sites and n2 with the second type of sites. The sorption capacity of this material was about $1500 \mathrm{mg} / \mathrm{g}$ at $30^{\circ} \mathrm{C}$. The potential of PACK, a readily available material to use as an alternative biosorbent material to eliminate the MB color from aqueous solutions was therefore confirmed.

Keywords: Adsorption; Isotherms; Kinetics; Methylene Blue; Physical models; Wastewater. 


\section{Introduction}

Water is the main raw material in our planet, vital for humans, animals, plants and microorganisms; all the vital phenomena of the biosphere are related to the availability of water. Water pollution affecting rivers, seas, groundwater and lakes is the result of the wastewater arising from many industrial discharges, repeatedly contaminated with diverse organic, inorganic and volatile compounds, such as benzene, toluene, phenol, heavy metals, suspended solids, etc[1]. This causes a degradation of the ecosystem. Among the industries that use water in large quantities are the tanning and textile industry, where it is used primarily for dyeing and finishing.These industries are one of the main sources of huge pollution problems in the world due to their water polluted with toxic dyes, even in small amounts. In fact, 100,000 varieties of textile dyes with an annual production estimated at 7.105 metric tons are available on the world market; $30 \%$ of these dyes are used at more than 1000 tons per year, and 90\% of textile products are used at 100 tons per year or less [2, 3]. 2 to $20 \%$ of textile dyes are diversified in liquid effluents during the dyeing process and can cause serious problems because their presence in water, even in very small amounts, is very visible and indisputable $[4,5]$. The treatment of industrial waste containing this type of dye has a great interest. Vast variety of biological, chemical and physical techniques has been developed and tested in the treatment of effluents filled with dyes, such as flocculation, precipitation, ion exchange, membrane filtration, irradiation and ozonation. However, the use of these processes is very costly and contributes to the creation of vast volumes of sludge [2, 6]. Adsorption remains one of the most favorable methods for removing dyes, due to its simplicity of use $[7,8]$. 
The principle of the adsorption treatment is to trap the dyes with a solid material, the adsorbent. There are several solid materials in the literature (biosorbents, clays, zeolites, activated carbons ...) that can be used in water bleaching processes. In recent years, research focuses on the use of costeffective adsorbents, available locally, biodegradable absorbents made from natural sources [9]. In this regard, biosorbents synthesized from lignocellulosic residues have been widely used as adsorbents to treat colored effluents, because of their very large porous structure, large surface area and high adsorption capacity. Among these adsorbents, we can mention among others: date stones [10], apple skin [11], olive stones (10), peach stones [13], corn cobs [14], coffee beans[15], and coffee grounds [16, 17], Tea waste [18], bagasse [19], coconut shell [20], apricot stones [21], fungi [22], algae [23], chitosan [24], bacteria [25]. Also, in recent times, Ash of Cassia fistula seeds [26], rice husk [27] , coconut shell and coal ash [28], Stipa tenassicima fibers [29], cones of Pinus brutia [30], wild carob [31], LDHs [32] and acid treated Cupressus semperirens cones pomegranate peel [33], as well as pectin from orange industry residues [34], polyacrylamidediatomite (PAA-D) [35], $\mathrm{Fe}_{3} \mathrm{O}_{4}$ [36], chitosan vermiculite beads [37], Pseudoevernia furfuracea [8], Orange Peel treated with $\mathrm{H}_{3} \mathrm{PO}_{4}$ [38] and particles of Ziziphus jujuba stones (BZJS1) [39].

Methylene blue is the most frequently used dye in cotton dyeing, wool, and silk. It causes breathing difficulties when there is an inhalation, a burning sensation if swallowed by mouth, causes nausea [5].

In the present study, we were interested in the removal of methylene blue (BM) dye using a new inexpensive and naturally abundant material Acorus calamus collected from the Sahara of Algeria, which is considered to be a potential material for adsorption of cationic dyes. Moreover and to our knowledge, no work has been reported in the literature on the use of this material for the elimination of dyes. In the present study, it was first treated with $\mathrm{H}_{2} \mathrm{SO}_{4}$ and then activated with 
$\mathrm{KMnO}_{4}$. The new material was called PACK. Various experimental parameters were analyzed, such as $\mathrm{pH}$, contact time, effect of the mass of adsorbent and effect of initial dye concentration. The effect of temperature on the adsorption of the dye was also studied and the thermodynamic parameters were determined. 


\section{Materials and methods}

\subsection{Materials}

The Acorus calamus collected from the Sahara of Algeria was used as biosorbent in this work. The following chemicals products were used, Methylene Blue (MB), $\mathrm{H}_{2} \mathrm{SO}_{4}(65 \%), \mathrm{KMnO}_{4}$, and humic acid. All the chemicals mentioned were purchased from Sigma-Aldrich

\subsection{Preparation of dye solutions and concentration determination}

Methylene Blue (MB), a typical cationic dye was selected as an adsorbate. Its chemical structure and some of its properties are presented in Figure 1 and Table 1. It was obtained from ACROS with 99.99\% purity.

Working solutions were prepared by dilution of the stock solution with distilled water to yield the appropriate concentrations. The $\mathrm{pH}$ of the solutions was adjusted by adding either $0.1 \mathrm{M} \mathrm{HCl}$ or $0.1 \mathrm{M} \mathrm{NaOH}$ solutions. Before use, all bottles and glassware were beforehand cleaned and then rinsed with distilled water and oven-dried at $60^{\circ} \mathrm{C}$. There residual dye concentrations were assessed by An SP-8001 UV/vis Spectrophotometer of Axiom (Germany, Shimadzu).

Table 1: Chemical properties of Methylene Blue.

\begin{tabular}{cccccc}
\hline Dye & Classification & $\lambda_{\max }(\mathrm{nm})$ & Empirical formula & $\begin{array}{c}\text { Formula weight } \\
\left(\text { g. mol }{ }^{-1}\right)\end{array}$ & Solubility \\
\hline $\begin{array}{c}\text { Methylene } \\
\text { Blue }\end{array}$ & Cationic dye & 664 & $\mathrm{C}_{16} \mathrm{H}_{18} \mathrm{~N}_{3} \mathrm{ClS}$ & 320 & $>$ 50g. L ${ }^{-1}$ \\
\hline
\end{tabular}

\subsection{Preparation of the adsorbent}

Aquatic reeds of Sahara (Algeria) were firsty washed with distilled water, then dried at a temperature of about $40^{\circ} \mathrm{C}$. This quantity was sieved and crushed to obtain small grains, generally 
less than $2 \mathrm{~mm}$. A first treatment was carried out with a mixture of sulfuric acid (65\%) and the aquatic reeds powder at a ratio of (1g (powder) / 20ml $\left(\mathrm{H}_{2} \mathrm{SO}_{4}\right)$ ); the reaction mixture was stirred at a temperature of $70{ }^{\circ} \mathrm{C}$ for 5 hours. The powder was filtered and washed several times with distilled water until purification and then dried in an oven overnight at $80{ }^{\circ} \mathrm{C}$. The resulting product was treated again with $\mathrm{KMnO} 4(1 \mathrm{M})$ at a ratio of (1g (powder) / 10ml (KMnO4)) at room temperature for 24 hours. The powder obtained was washed until purification and then dried in an oven overnight at $80^{\circ} \mathrm{C}$. It was then stored in desiccator for future use. The obtained product, namely powder of Acorus Calamus $\mathrm{KMnO}_{4}$-activated, was abbreviated as PACK.

\subsection{Characterization of the adsorbent}

\subsubsection{Infrared spectroscopy (IRTF)}

FTIR analysis enables to determine the functional surface groups of materials. This analysis was conducted on a Spectrum Two-type infrared spectroscopy apparatus using the technique of highpressure $\mathrm{KBr}$ granules; the analysis was done over a wavelength range of $400-4000 \mathrm{~cm}^{-1}$.

\subsubsection{The Point of Zero Charge of PACK}

The $\mathrm{pHpzc}$ ( $\mathrm{pH}$ of the zero or no charge point) refers to the $\mathrm{pH}$ value at which the net charge on the adsorbent surface is null. This parameter is very important in adsorption phenomena, especially when electrostatic forces are involved in the mechanism. A quick and simple protocol to determine the pHpzc consists in placing $50 \mathrm{ml}$ of the distilled water in closed vials and then adjusting the $\mathrm{pH}$ of each (values between 2 and 12) by addition of $\mathrm{NaOH}(0.1 \mathrm{M})$ or $\mathrm{HCl}(0.1 \mathrm{M})$ solution. $25 \mathrm{mg}$ of PACK material was added to each vial. The suspension was agitated at room temperature around 24 hours, and then the final $\mathrm{pH}$ was determined. 


\subsubsection{Scanning electron microscopy (SEM)}

Scanning electron microscopy (SEM) of PACK biosorbent before biosorption was visualized using Hitachi S-3000 N SEM at $10 \mathrm{kV}$ and various magnifications, 500 and 20,000. From the SEM, it is possible to see the topography surface of the material.

\subsection{Adsorption studies}

\subsubsection{Adsorption kinetics}

The effect of the contact time on the adsorption of methylene blue (MB) on the PACK material was considered in this study at the natural $\mathrm{pH}, 6.5$. Experiments were performed, adding a given amount of biosorbent $(50 \mathrm{mg})$ in $200 \mathrm{ml}$ of dye solutions of known concentrations (100 and 150 $\mathrm{mg} / \mathrm{L}$ ) in two conical flasks $(500 \mathrm{ml})$ with continuous stirring $(250 \mathrm{rpm})$ at $25 \pm 2^{\circ} \mathrm{C}$. After withdrawing samples at fixed time intervals and centrifugation, the supernatants were analyzed for residual MB. The amount of dye adsorbed $\mathrm{Q}_{\mathrm{t}}(\mathrm{mg} / \mathrm{g})$ at time $\mathrm{t}$, was calculated according to Eq. 1 .

$$
\mathrm{Q}_{\mathrm{t}}=\frac{\left(\mathrm{C}_{0}-\mathrm{C}_{\mathrm{t}}\right) \mathrm{V}}{\mathrm{m}}
$$

Where $\mathrm{C}_{0}$ and $\mathrm{C}_{\mathrm{t}}(\mathrm{mg} / \mathrm{L})$ are the dye concentrations in the solution at the beginning and after time $\mathrm{t}, \mathrm{V}(\mathrm{L})$ and $\mathrm{m}(\mathrm{g})$ are respectively the volume of the solution and the mass of dry biosorbent.

\subsubsection{Kinetics modeling}

Kinetics provide information on the adsorption process and the type of solute migration from the liquid phase to the solid phase. For this purpose, some models were considered to fit experimental data, the pseudo-first-order, pseudo-second-order (PSO) (PFO) [40, 41] and pseudo- ${ }^{\text {th }}$ order (PNO) [42, 43]. The models formulas and their parameters are gathered in Table 2. 
Table 2: Adsorption kinetics models used in this work and their parameters.

\begin{tabular}{|c|c|c|}
\hline Kinetics models & Equation & Parameters \\
\hline Pseudo-first order & $\mathrm{Q}_{\mathrm{t}}=\mathrm{Q}_{\mathrm{e}}\left(1-\mathrm{e}^{-\mathrm{k}_{1} \mathrm{t}}\right)$ & $\begin{array}{l}\mathrm{Q}_{\mathrm{e}}\left(\mathrm{mg} \mathrm{g}^{-1}\right) \text { and } \mathrm{Q}_{\mathrm{t}}\left(\mathrm{mg} \mathrm{g}^{-1}\right) \text { refer to the } \\
\text { amount of dye adsorbed at equilibrium } \\
\text { and at time } \mathrm{t}(\mathrm{min}) \text { respectively. }\end{array}$ \\
\hline & & 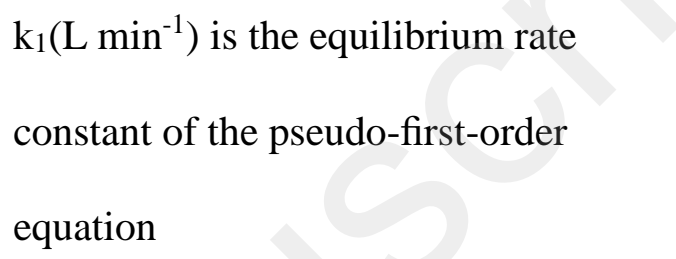 \\
\hline $\begin{array}{l}\text { Pseudo-second } \\
\text { order }\end{array}$ & $\mathrm{Q}_{\mathrm{t}}=\frac{\mathrm{k}_{2} \mathrm{Q}_{\mathrm{e}}{ }^{2} \mathrm{t}}{1+\mathrm{k}_{2} \mathrm{Q}_{\mathrm{e}} \mathrm{t}}$ & $\begin{array}{l}\mathrm{k}_{2}\left(\mathrm{~L} \min ^{-1}\right) \text { is the equilibrium rate } \\
\text { constant of the pseudo-second-order } \\
\text { equation }\end{array}$ \\
\hline Pseudo- $\mathrm{n}^{\text {th }}$ order & $Q_{t}=Q_{e}-\left[(n-1) k_{n} t+Q_{e}^{(n-1)}\right]^{\frac{1}{1-n}}$ & $\begin{array}{l}\mathrm{k}_{\mathrm{n}} \text { is a constant and } \mathrm{n} \text { is the biosorption } \\
\text { reaction order }\end{array}$ \\
\hline
\end{tabular}

\subsubsection{Adsorption isotherms}

The adsorption isotherm is a representative characteristic of the thermodynamic equilibrium between the adsorbent and the adsorbate [29]. It is very useful for understanding the adsorption mechanism; it gives information about the affinity, the binding energy between the adsorbate and the adsorbent, and about the adsorption capacity. Experiments were carried out in a series of Erlenmeyer flasks (50 ml) placed on a multi-station magnetic stirrer shaken at $250 \mathrm{rpm}$ and loaded with $50 \mathrm{ml}$ of $\mathrm{MB}$ at different concentrations (in the range 50 to $1100 \mathrm{mg} \mathrm{L}^{-1}$ ). $25 \mathrm{mg}$ of the PACK material was added to each Erlenmeyer; the mixture was stirred for 24 hours, and the process was 
repeated for two temperatures 20 and $30^{\circ} \mathrm{C}$. Adsorption capacity $\mathrm{Q}_{\mathrm{e}}\left(\mathrm{mg} \cdot \mathrm{g}^{-1}\right)$ was calculated based on Eq. (2).

$$
\mathrm{Qe}=\frac{\left(\mathrm{C}_{0}-\mathrm{C}_{\mathrm{e}}\right) \mathrm{V}}{\mathrm{m}}
$$

Where $\mathrm{C}_{0}$ and $\mathrm{C}_{\mathrm{t}}(\mathrm{mg} / \mathrm{L})$ are the dye concentrations in the solution at the beginning and after time $\mathrm{t}$ respectively, $\mathrm{V}(\mathrm{L})$ is the solution volume and $\mathrm{m}(\mathrm{g})$ is the dry adsorbent mass.

\subsubsection{Isotherm modeling}

Mathematical modeling of isotherms provides a relationship between solute concentration in solution and adsorbed quantity per unit mass of adsorbent [44]. The two most commonly used twoparameter models are the Langmuir and Freundlich models; the Dubinin Radushkevich (D-R) model was also considered. However, to go a little further in the understanding of adsorption mechanisms, three-parameter models like the sips model and the Redlich-Petrson model were also considered. Table 3 describes these isotherm models and their parameters.

Table 3: Adsorption isotherm models adopted in this work and their parameters.

\begin{tabular}{lll}
\hline Isotherm & Equation & Parameters \\
\hline & $\mathrm{Q}_{\mathrm{e}}\left(\mathrm{mg} \mathrm{g}^{-1}\right)$ is the amount of $\mathrm{MB}$ adsorbed per \\
& unit mass of adsorbent \\
Langmuir $\quad \frac{\mathrm{Q}_{\mathrm{e}}}{\mathrm{Q}_{\mathrm{m}}}=\frac{\mathrm{K}_{\mathrm{L}} \mathrm{C}_{\mathrm{e}}}{1+\mathrm{K}_{\mathrm{L}} \mathrm{C}_{\mathrm{e}}}$ & $\mathrm{C}_{\mathrm{e} .}\left(\mathrm{mg} \mathrm{L}^{-1}\right)$ the equilibrium dye concentration \\
& in solution \\
& $\mathrm{Q}_{\mathrm{m}}\left(\mathrm{mg} \mathrm{g}^{-1}\right)$ the monolayer capacity of the \\
& adsorbent \\
& $\mathrm{K}_{\mathrm{L}}$ the Langmuir constant \\
\end{tabular}




\begin{tabular}{|c|c|c|}
\hline & & $\mathrm{K}_{\mathrm{F}}$ and $\mathrm{n}^{-1}$ are empirical constants indicative of \\
\hline Freundlich & $\mathrm{Q}_{\mathrm{e}}=\mathrm{K}_{\mathrm{F}} \mathrm{C}_{\mathrm{e}}^{1 / \mathrm{n}}$ & $\begin{array}{l}\text { sorption capacity and sorption intensity. } \\
\text { respectively }\end{array}$ \\
\hline Sips & $\frac{\mathrm{Q}_{\mathrm{e}}}{\mathrm{Q}_{\mathrm{m}}}=\frac{\left(\mathrm{K}_{\mathrm{s}} \mathrm{C}_{\mathrm{e}}\right)^{m}}{1+\left(\mathrm{K}_{\mathrm{s}} \mathrm{C}_{\mathrm{e}}\right)^{m}}$ & $\begin{array}{l}\mathrm{K}_{\mathrm{s}} \mathrm{i}\left(\mathrm{L} \mathrm{mg}^{-1}\right) \text { the Sips constant } \\
\mathrm{m} \text { the exponent of the Sips model }\end{array}$ \\
\hline Redlich-Peterson & $\mathrm{Q}_{\mathrm{e}}=\frac{\mathrm{k}_{\mathrm{R}} \mathrm{C}_{\mathrm{e}}}{1+\alpha_{\mathrm{R}} \mathrm{C}_{\mathrm{e}}^{\beta_{\mathrm{R}}}}$ & $\begin{array}{l}\mathrm{k}_{\mathrm{R}}\left(\mathrm{L} \mathrm{g}^{1}{ }^{1}\right) \text { is the Redlich-Peterson (R-P) } \\
\text { isotherm constant } \\
\alpha_{\mathrm{R}}\left(\mathrm{L} \mathrm{mg}^{-1}\right) \text { is also having a constant unit of } \\
\beta_{\mathrm{R}} \text { is an exponent }\end{array}$ \\
\hline $\begin{array}{c}\text { Dubinin- } \\
\text { Radushkevich }\end{array}$ & $\mathrm{Qe}=\mathrm{Q}_{\mathrm{DR}} \exp \left(-\mathrm{k}_{\mathrm{DR}} \varepsilon^{2}\right)$ & $\begin{array}{l}\text { QDR is capacity of the adsorbent }(\mathrm{mg} / \mathrm{g}) \\
\mathrm{K}_{\mathrm{DR}} \text { is the activity coefficient }\left(\mathrm{mol}^{2} \mathrm{KJ}^{2}\right) \\
E_{\mathrm{DR}} \text { The biosorption energy }\left(\mathrm{kJ} \mathrm{mol}^{-1}\right),\left(\mathrm{E}_{\mathrm{DR}}=\right. \\
\left.\left(2 \mathrm{~K}_{\mathrm{DR}}\right)^{-0.5}\right) \\
\varepsilon \text { stands for constant related to the biosorption } \\
\text { energy }(\varepsilon=\mathrm{RT} \ln (1+1 / \mathrm{Ce}))\end{array}$ \\
\hline
\end{tabular}

\subsection{Statistical physics}

In an attempt to understand the adsorption phenomenon by means of statistical physics processing, the following hypotheses were assumed:(i) it was considered that a variable amount of solute molecules were adsorbed on interstitial Nm sites of the adsorbent (unit mass); (ii) adsorption reaction of solute molecule (A) at an interstitial site (S) must include a stoichiometric coefficient $\mathrm{n}$ according to the following reaction[45]:

$\mathrm{nA}+\mathrm{S} \leftrightarrow \mathrm{A}_{\mathrm{n}} \mathrm{S}$ 
Depending on the value of $\mathrm{n}$, two different ways of adsorption of the solute on the adsorbent can be distinguished. If $\mathrm{n}$ is less than 1 , only a fraction of solute molecules are adsorbed; it consists in multi-anchorage adsorption. In the second case, if $\mathrm{n}$ is greater than 1 , it is an interstitial site filled with more than one molecule; this case corresponds to multi-molecular adsorption [46].

Statistical physical simulation is used in this study to explain the adsorption of MB in the PACK material. For a system in specific physical conditions, we used the large canonical partition function $z_{g c}$ which describes the microscopic state:

$z_{g c}=\sum_{N_{i}} e^{-\beta(-\varepsilon-\mu) N_{i}}$

Where $\mathrm{Ni}$ is the receptor site occupation state, $\mu$ is the chemical potential, $\varepsilon i$ is the receptor site adsorption energy, and $\beta$ is defined as $1 / \mathrm{kBT}$ (where $\mathrm{T}$ is the absolute temperature and $\mathrm{kB}$ is the Boltzmann constant).

The MB adsorption isotherms are simulated by three different models of statistical physics, monolayer single-energy, monolayer two-energy, and double-layer two-energy models [45].

The three models are summarized in the following table (Table 4). 
Table 4: Grand canonical partition function and equation of the three models of statistical physics

\begin{tabular}{lcc}
\hline Model & Grand canonical partition function & Equation \\
\hline 1 & $z_{g c}=\sum_{N_{i}=0.1} 1+e^{\beta(\varepsilon+\mu) N_{i}}$ & $\mathrm{Q}=\frac{\mathrm{n} \cdot \mathrm{Nm}}{1+\left(\frac{\mathrm{C}_{1 / 2}}{\mathrm{Ce}}\right)^{\mathrm{n}}}$ \\
2 & $z_{g c}=\left(1+e^{\beta\left(\varepsilon_{1}+\mu\right)}\right)^{N_{1 m}}$ & $\mathrm{Q}=\frac{\mathrm{n} 1 \cdot \mathrm{Nm} 1 .}{1+\left(\frac{\mathrm{C} 1}{\mathrm{Ce}}\right)^{\mathrm{n} 1}}+\frac{\mathrm{n} 2 \cdot \mathrm{Nm} 2}{1+\left(\frac{\mathrm{C} 2}{\mathrm{Ce}}\right)^{\mathrm{n} 2}}$ \\
3 & $\left.z_{g c}=\sum_{1} 1+e^{\beta(\varepsilon+\mu)}+e^{\left.2 \beta(\varepsilon+\mu) N_{m}+\mu\right)}\right)^{N_{2 m}}$ & $Q=n \cdot N_{M} \cdot \frac{\left(\frac{C}{C 1}\right)^{n}+2 \cdot\left(\frac{C}{C 2}\right)^{2 n}}{1+\left(\frac{C}{C 1}\right)^{n}+2 \cdot\left(\frac{C}{C 2}\right)^{2 n}}$ \\
\end{tabular}

In model 1, it is assumed that the adsorption of the dye takes place by a monolayer single-energy model [47]. The receptor sites can interact with several dye molecules. The quantity adsorbed $\mathrm{Q}_{\mathrm{e}}$ as a function of $C_{e}$ is given by Eq.1 in the Table 4 [48].

Where the parameter $\mathrm{n}$ represents the number of MB molecules captured per active site of PACK, the density of the adsorbent receptor sites is $\mathrm{Nm}$ and the concentration at half-saturation is $\mathrm{C}_{1 / 2}$.

In model 2, monolayer two-energy, the adsorption of MB is assumed on two different sites of PACK with two different energy, E1 for the first site and E2 for the second site. The receptor sites can interact with a variable number of MB molecules, $\mathrm{n} 1$ with the first site (type one) and $\mathrm{n} 2$ with the second site (type two). The evolution of Qe as a function of Ce is given by the Eq. 2 in Table 4. In the equation 4, Nm1 and $\mathrm{Nm} 2$ are the first and the second type densities of adsorbent receptor sites respectively, $\mathrm{C}_{1}$ and $\mathrm{C}_{2}$ are the concentration at half-saturation of the first and of the second receptor site. 
For model 3, namely double-layer two-energy model, $E_{1}$ and $E_{2}$ are related to the first and the second layer, with the second layer having less energy than the first [49]. From this, the quantity Qe adsorbed as a function of $\mathrm{C}_{\mathrm{e}}$ is given by Eq.3 in Table 4 [50].

Where $\mathrm{C}_{1}$ and $\mathrm{C}_{2}$ are the concentrations of the first and second layers at half-saturation, respectively.

\subsection{Statistical assessment of equilibrium parameters}

Evaluation of nonlinear adsorption isotherms by the error function ( $\left.F_{\text {error }}\right)$ represented by Eq.5 was conducted. This function allows to compare the experimental data point by point with those obtained by the adjusted model. Models with a low $F_{\text {error }}$ value are the most appropriate for describing the experimental behavior:

$$
\mathrm{F}_{\text {error }}=\sqrt{\sum_{1}^{\mathrm{P}}\left(\frac{1}{\mathrm{P}-1}\right) \cdot\left(\frac{\mathrm{Q}_{\mathrm{i}, \text { mod }}-\mathrm{Q}_{\mathrm{i}, \text { exp }}}{\mathrm{Q}_{\mathrm{i}, \text { exp }}}\right)}
$$

Where $\mathrm{Q}_{\mathrm{i}, \mathrm{mod}}$ is the adsorption capacity of the adsorbent given by the model; $\mathrm{Q}_{\mathrm{i}, \mathrm{exp}}$ is the experimental adsorption capacity, and $\mathrm{P}$ is the number of experimental points [51].

\subsection{Parameters governing adsorption phenomena}

\subsubsection{The effect of the initial $\mathrm{pH}$ on adsorption}

The $\mathrm{pH}$ is a very important factor in the adsorption phenomenon. The surface charge and the distribution of ions of the material may change significantly with $\mathrm{pH}$. The effect of $\mathrm{pH}$ on the adsorption of MB on PACK has been studied at different initial $\mathrm{pH}$ (in the range 3 to 12). The $\mathrm{pH}$ adjusted to the desired values with $\mathrm{HCl}(1 \mathrm{M})$ and $\mathrm{NaOH}(1 \mathrm{M})$. The initial concentration of $\mathrm{MB}$ 
was160 mg/l (stock solution). The other parameters, such as the tank volume, temperature, stirring speed, and adsorbate mass were $\mathrm{V}=50 \mathrm{ml}, \mathrm{T}=25 \pm 2^{\circ} \mathrm{C}$, stirring speed $=250 \mathrm{rpm}, \mathrm{m}_{\text {PACK }}=25 \mathrm{mg}$.

\subsubsection{The effect of humic acid on the adsorption}

Textile wastewater, as it is known contains variable concentrations of organic and inorganic ions, mainly cations and anions such as nitrates, chlorides, sulfates, carbonates and hydrogenocarbonates. In this part, the effect of humic acids on adsorption was examined to better understand their effect on the adsorption of MB on the adsorbent. Indeed, humic acids can be found in nature in significant quantities. Therefore, different humic acid quantities (5, 20, 30, and $50 \mathrm{mg}$ ) were added in $50 \mathrm{ml}$ of a solution of $\mathrm{MB}$ at $800 \mathrm{mg} / \mathrm{L}$ in the presence of $25 \mathrm{mg}$ of adsorbent. After stirring until the equilibrium time the results obtained were compared to the result of adsorption without humic acid.

\subsubsection{Effect of the biosorbent dose on biosorption}

The ratio of biosorbent-solution is an important factor in assessing the biosorption capacity of the material biosorbent. In order to examine the impact of the initial dose of PACK biosorbent on the MB dye, a range of doses between 10 to $100 \mathrm{mg}$ of adsorbent was examined in the presence of 400 $\mathrm{mg} / \mathrm{L}$ initial dye concentration. 


\section{Result and discussions}

\subsection{Characterization of the adsorbent}

\subsubsection{Infrared spectroscopy (FT-IR) interpretation of PACK material}

The FT-IR spectrum of the PACK material before adsorption (Figure 2) gives certain absorption bands that can be defined by the following functional groups. A broad absorption band of about 3600-3000 $\mathrm{cm}^{-1}$ which characterizes the vibration of elongation of hydrogen from hydroxyl groups $\mathrm{OH}^{-}$(phenol, alcohols, or carbonyls). It can also correspond to the vibration of elongation of the $\mathrm{OH}^{-}$groups of cellulose (lignin and pectin). Another band at $2360 \mathrm{~cm}^{-1}$ may correspond to the presence of $\mathrm{a}=\mathrm{N}-\mathrm{H}$ bond. The characteristic band between $1640 \mathrm{~cm}^{-1}$ and $1530 \mathrm{~cm}^{-1} \mathrm{can}$ be identified as the carboxylic group bonding ionic (COO-) elongation vibrations and can be assigned to the $\mathrm{C}=\mathrm{C}$ aromatic stretching. The characteristic band at $1380 \mathrm{~cm}^{-1} \mathrm{can}$ be related to the $\mathrm{C}-\mathrm{H}$ and O-H deformation vibration in hydroxyls, phenols, methyl and olefins. For the comparison between the two FT-IR spectra before and after adsorption, similar peaks of different intensity were observed with the appearance of new peaks such as: at $1321 \mathrm{~cm}^{-1}$, a characteristic band attributed to the valence vibrations of the aliphatic C-H groups existing in the structure of the MB. The peek at $1120 \mathrm{~cm}^{-1}$ corresponds to the mode of vibration and elongation of the aromatic groups $\mathrm{C}-\mathrm{H}$ existing in the structure of the MB; another band at $665 \mathrm{~cm}^{-1}$ may correspond to the presence of a $\mathrm{C}-\mathrm{S}$ bond existing in the structure of the MB. These peaks confirmed the adsorption of MB onto the PACK material. 


\subsubsection{The Point of Zero Charge}

From the graph presented in Figure 3, the pHpzc of adsorbate was equal to 8.3, which means that the surface of PACK was positively charged when the $\mathrm{pH}$ of the solution was lower than 8.3 and negatively charged when the $\mathrm{pH}$ of the solution was higher than 8.3.

\subsubsection{Scanning electron microscopy (SEM)}

It can be seen the SEM surface images of PACK in Figure 4. The images obtained at a one and ten micron-meter scale showed a heterogeneous surface morphology composed of many cavities (micro-pores) of different sizes. This irregular morphology of the material can facilitate the sorption of $\mathrm{MB}$, and we can consequently assume that the PACK material represented an appropriate morphological profile for the adsorption of dyes [52].

\subsection{Kinetics analysis}

Two initials concentrations, 100 and $150 \mathrm{mg} / \mathrm{L}$ were considered. As expected, the adsorption capacity of PACK increased with the increase of the initial dye concentrations. As shown in Figure 5, biosorption increased rapidly during the first 90 minutes, before reaching equilibrium, for both considered concentrations. According to adsorption kinetics, more information on the adsorption mechanism (adsorbent/adsorbate) or in another way the transfer of a solute from the liquid phase to the solid phase can be provided. For this purpose, several kinetic models, namely the pseudofirst kinetic model (PFO), pseudo-second-order model (PSO) and pseudo- $\mathrm{n}^{\text {th }}$ order model (PNO) were applied to explain the adsorption mechanism. Figure 5 and Table 5 shows the parameters obtained with the different kinetic models for the adsorption of MB onto the PACK material. It can be seen from this table, that all models accurately fitted experimental data, leading to 
coefficients of correlation between 0.95 and 0.997 ; however, the values of the coefficients of correlation given by the PSO model were slightly lower than those given by PFO and PNO (Table 5). In addition, theoretically calculated Qt (373.87mg/g and $604.37 \mathrm{mg} / \mathrm{g}$ ) values from the PNO model agreed very well with the experimental Qt (374mg/g and $547 \mathrm{mg} / \mathrm{g}$ ) values, for both 100 and $150 \mathrm{mg} / \mathrm{L}$ dye respectively, if compared to those obtained by the PFO and PSO models. Moreover, the rates constants (K1, K2, and Kn) for all models, declined in a significant way when the initial MB concentration increased from 100 to $150 \mathrm{mg} / \mathrm{L}$. Furthermore, the coefficient $\mathrm{n}$ of the PNO increased from 1.31 to 2.5 for 100 and $150 \mathrm{mg} / \mathrm{L}$ initial dye amount, respectively. From this, it can be inferred that the order of the reaction was greater than 2 for $150 \mathrm{mg} / \mathrm{L}$ dye. In summary, according to the modeling results, it can be considered that experimental data were most accurately fitted in this order PNO $>$ PFO $>$ PSO models.

Tableau 5: Kinetic parameters and correlation coefficients for nonlinear regression of PFO, PSO and PNO models for the adsorption of MB onto PACK at room temperature.

\begin{tabular}{cclcc}
\hline Material & Model & Parameters & $\mathbf{1 0 0}$ & $\mathbf{1 5 0}$ \\
\hline \multirow{4}{*}{ PACK } & Qexp & $\mathbf{3 7 4}$ & $\mathbf{5 4 7}$ \\
& PFO & Qe & 368.88 & 528.05 \\
& & $\mathrm{~K}_{1}$ & 0.153 & 0.093 \\
& & $\mathbf{R}^{2}$ & $\mathbf{0 . 9 9 4}$ & $\mathbf{0 . 9 4 9 4}$ \\
\cline { 3 - 5 } & Qe & 391.46 & 572.70 \\
& & $\mathrm{~K}_{2} * 10^{+4}$ & 6.94 & 2.60 \\
& & $\mathbf{R}^{2}$ & $\mathbf{0 . 9 8 9}$ & $\mathbf{0 . 9 8 6}$ \\
\cline { 3 - 5 } & & Qe & 373.87 & 604.37 \\
& PNO & $\mathrm{k}_{\mathrm{n}}$ & 0.029 & $1.16 \mathrm{E}-05$ \\
& $\mathrm{n}$ & 1.31 & 2.50 \\
& & $\mathbf{R}^{2}$ & $\mathbf{0 . 9 9 7}$ & $\mathbf{0 . 9 8 6}$ \\
\hline
\end{tabular}




\subsection{Isotherm analysis}

Adsorption isotherm is very important both theoretically and practically to optimize an adsorption system; the corresponding results are shown in Figure 6. The two isotherms showed an L-type appearance (Langmuir type). The L shape of an adsorption isotherm means that there is no strong competition between the solvent and the adsorbent to occupy the adsorption sites; consequently, the affinity between the adsorbate and the adsorbent is relatively high. This was confirmed by the modeling of the adsorption isotherms (the affinity between the adsorbent and the adsorbate increased when the value of the $\mathrm{K}_{\mathrm{L}}$ constant decreased). The maximum values of the adsorption capacity at equilibrium were $1285.34 \mathrm{mg} / \mathrm{g}$ and $1528.02 \mathrm{mg} / \mathrm{g}$ for the two temperatures, 20 and 30 ${ }^{\circ} \mathrm{C}$ respectively. According to the results obtained, there was a positive temperature effect on the adsorption of MB-PACK. To properly define the sorption process for the elimination of dyes from the effluent, the most appropriate correlation for the equilibrium data should be determined. Isotherm models cited in Table 3 were used and the fitting was carried out using the MarquardLevenberg program. It is clear that the adsorption capacity increased with increasing equilibrium concentration of $\mathrm{MB}$ and reached saturation progressively for all tested models. In the case of the two-parameter models, both Langmuir and Dubinin-Radushkevich isotherm models were the most appropriate to describe experimental data. The calculated parameters are provided in Table 6 and the corresponding graphs are shown in Figure 6. It can be seen from Table 6, that the values of the coefficient of determination, $\mathrm{R}^{2}$, obtained for Langmuir and Dubinin-Radushkevich (D-R) were closer to 1.00, if compared to those given by the Freundlich model. From this, the biosorption of the MB molecules was localized without adsorbate-adsorbent interactions [53]. The adsorption capacity for Langmuir and Dubinin-Radushkevich (D-R) (Table 6) using nonlinear regression was found to increase from $1219.83 \mathrm{mg} / \mathrm{g}$ to $1522.34 \mathrm{mg} / \mathrm{g}$ and from $1096.76 \mathrm{mg} / \mathrm{g}$ to $1419.95 \mathrm{mg} / \mathrm{g}$ 
for Langmuir and Dubinin-Radushkevich (D-R) respectively, namely close to those found experimentally for an increase in temperatures from 20 to $30^{\circ} \mathrm{C}$. The biosorption constant, $\mathrm{K}_{\mathrm{L}}$, decreased from $256 \mathrm{~L} / \mathrm{mg}$ to $219 \mathrm{~L} / \mathrm{mg}$ for the Langmuir model as temperatures varied from 20 to $30{ }^{\circ} \mathrm{C}$. Besides, from Table 6, it can be evaluated that the adsorption behavior of MB onto PACK fitted very well with the Langmuir isotherm model, better than the Freundlich model as reflected by the correlation coefficients and the $\mathbf{F}_{\text {error }}$ of the experimental data.

On the other hand, the three-parameter models, R-P, and Sips Eqs. were also applied to examine the adsorption of MB. The calculated isotherm parameters and their corresponding coefficient of determination $\mathrm{R}^{2}$ values are also given in Table 6 . The high values of $\mathrm{R}^{2}$ and the low values of $\mathrm{F}_{\text {error }}$ for the the R-P model suggest the applicability of this model to represent the equilibrium sorption of MB on PACK in comparison to the sips model. Several studies showed that the R-P isotherm was more accurate than the Langmuir and Freundlich isotherms as it contains three unknown parameters. Indeed, the Langmuir and Freundlich isotherms can result from the R-P isotherm. Indeed, for $\beta_{R}=1$, the R-P Eq. becomes the Langmuir isotherm and for $\beta_{R}=0$, it is closer to the Freundlich Eq. Otherwise, the Sips model is the combination of Langmuir and Freundlich models. From this and Table 6, it is not surprising that the adsorption capacity obtained from the Langmuir, Sips and R-P models could be more realistic than that from the Freundlich Eq. Moreover, the Redlich-Peterson (R-P) model was close to the Sips and Langmuir isotherms in the range of studied temperatures (when $m$ and $\beta$ value approach to 1). The isotherm constant $\alpha_{R}$ decreased with temperature; while inversely, the $\beta_{R}$ exponent increased with temperature. From Table 6 , we can note that the $\beta_{R}$ values were close to unity (i.e. the Langmuir model was appropriate to describe experimental data). Finally and regarding the statistical parameters given by $\mathrm{F}_{\text {error }}$ and $\mathrm{R}^{2}$, it can be noted that the R-P model was the most suitable to describe experimental 
data owing to its low $\mathrm{F}_{\text {error }}$ and the high $\mathrm{R}^{2}$, compared to the other models in the range of temperatures considered.

In addition, The Dubinin-Radushkevich (D-R) isotherm model provides information about whether the adsorption process is physical or chemical depending on its measured EDR parameter; if the $E_{D R}$ value is between $8-16 \mathrm{KJmol}^{-1}$ the adsorption process is a chemisorption process and if $\mathrm{E}_{\mathrm{DR}}<8 \mathrm{KJ} \mathrm{mol}^{-1}$ it is a physisorption process) [54]. It is worth noting that $\mathrm{E}_{\mathrm{DR}}$ is independent of the temperature; it depends on the nature of the adsorbate-adsorbent couple [55]. From the D-R model, the sorption energy $E_{D R}$ was $0.65 \mathrm{KJ} \mathrm{mol}^{-1}$, namely within the range of values for physical adsorption reactions. This result suggested that the biosorption process of the MB dye onto PACK biosorbent was physical in nature because the biosorption energy was less than $8 \mathrm{KJ} \mathrm{mol}^{-1}$.

Tableau 6. Langmuir. Freundlich. Sips, Redlich-Peterson (R-P) and Dubinin-Radushkevich (DR) constants for the adsorption of MB onto PACK

\begin{tabular}{|c|c|c|c|c|}
\hline & & & $20^{\circ} \mathrm{C}$ & $30^{\circ} \mathrm{C}$ \\
\hline & & $Q_{\exp }(\mathrm{mg} / \mathrm{g})$ & 1285.34 & 1528.02 \\
\hline & \multirow{4}{*}{ Langmuir } & $\mathrm{Q}_{\mathrm{m}}(\mathrm{mg} / \mathrm{g})$ & 1219.23 & 1522.34 \\
\hline & & $\mathrm{K}_{\mathrm{L}}(\mathrm{L} / \mathrm{mg}) \times 10^{3}$ & 0.256 & 0.219 \\
\hline & & Ferror & 0.365 & 0.926 \\
\hline & & $\mathbf{R}^{2}$ & 0.949 & 0.992 \\
\hline & \multirow{4}{*}{ Freundlich } & $1 / \mathrm{n}$ & 0.22 & 0.24 \\
\hline & & $\mathrm{K}_{\mathrm{F}}(\mathrm{mg} / \mathrm{g})(\mathrm{L} / \mathrm{mg})^{1 / \mathrm{n}}$ & 381.59 & 414.21 \\
\hline \multirow{7}{*}{ PACK } & & Ferror & 0.857 & 0.950 \\
\hline & & $\mathrm{R}^{2}$ & 0.843 & 0.877 \\
\hline & \multirow{5}{*}{ Sips } & $\mathrm{Q}_{\mathrm{m}}(\mathrm{mg} / \mathrm{g})$ & 1176.18 & 1502.57 \\
\hline & & $\mathrm{K}_{\mathrm{S}}(\mathrm{L} / \mathrm{mg})$ & 0.299 & 0.235 \\
\hline & & $\mathrm{m}$ & 1.26 & 1.08 \\
\hline & & Ferror & 0.471 & 0.329 \\
\hline & & $\mathbf{R}^{2}$ & 0.948 & 0.992 \\
\hline
\end{tabular}




\begin{tabular}{llcc}
\hline & $\mathrm{k}_{\mathrm{R}}(\mathrm{L} / \mathrm{g})$ & 341.261 & 343.545 \\
& $\alpha_{\mathrm{R}}(\mathrm{L} / \mathrm{mg})$ & 0.325 & 0.238 \\
Redlich-Peterson & $\beta_{\mathrm{R}}$ & 0.969 & 0.989 \\
& Ferror $^{2}$ & $\mathbf{0 . 3 8 6}$ & $\mathbf{0 . 3 2 2}$ \\
& $\mathbf{R}^{2}$ & $\mathbf{0 . 9 4 7 7}$ & $\mathbf{0 . 9 9 1}$ \\
\hline \multirow{3}{*}{ Dubinin- } & $\mathrm{Q}_{\mathrm{DR}}(\mathrm{mg} / \mathrm{g})$ & 1096.76 & 1419.95 \\
Radushkevich & $\mathrm{K}_{\mathrm{DR}} * 10^{6}$ & $\mathbf{0 . 7 7}$ & 1.20 \\
& $\mathrm{R}^{2}$ & $\mathbf{0 . 9 8 3}$ & $\mathbf{0 . 9 8 8}$ \\
\hline
\end{tabular}

\subsection{Statistical physics}

According to the results obtained by the three statistical models used in this study (Figure7), it seems that the two-energy monolayer model led to the most accurate modeling results according to the $\mathrm{R}^{2}$ values obtained (Table 7 ) for the two temperatures tested (20 and $30{ }^{\circ} \mathrm{C}$ ). The two other models were therefore not further considered in the interpretations of the different parameters since they gave lower $\mathrm{R}^{2}$ values.

Table 7: Results of calculations of the various anchoring parameters

\begin{tabular}{|c|c|c|c|c|c|c|c|c|}
\hline \multicolumn{3}{|c|}{ Model 1} & \multicolumn{4}{|c|}{ Model 2} & \multicolumn{2}{|c|}{ Model 3} \\
\hline & $20^{\circ} \mathrm{C}$ & $30^{\circ} \mathrm{C}$ & 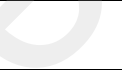 & $20^{\circ} \mathrm{C}$ & $30^{\circ} \mathrm{C}$ & & $20^{\circ} \mathrm{C}$ & $30^{\circ} \mathrm{C}$ \\
\hline n & 1.262 & 1.079 & $\mathbf{n}_{1}$ & 1.775 & 3.553 & $\mathrm{n}$ & 1.26 & 1.078 \\
\hline Nm & 931.99 & 1392.80 & Nm1 & 548.26 & 101.82 & Nm & 932.48 & 1392.73 \\
\hline $\mathrm{C}_{1 / 2}$ & 3.3464 & 4.259 & $C_{1}$ & 2.433 & 1.289 & $C_{1}$ & 3.347 & 4.259 \\
\hline \multirow[t]{4}{*}{$\mathbf{R}^{2}$} & 0.9778 & 0.9966 & $\mathbf{n}_{2}$ & 1.957 & 1.025 & $\mathrm{C}_{2}$ & 732.22 & 753.18 \\
\hline & & & $\mathrm{Nm}_{2}$ & 173.94 & 1146.87 & $\mathbf{R}^{2}$ & 0.9778 & 0.9966 \\
\hline & & & $\mathrm{C}_{2}$ & 113.86 & 8.326 & & & \\
\hline & & & $\mathbf{R}^{2}$ & 0.9873 & 0.9996 & & & \\
\hline
\end{tabular}




\subsubsection{Steric parameters ni and $\mathrm{Nmi}$}

The steric parameters $\mathrm{n}_{1}$ and $\mathrm{n}_{2}$ of the two-energy monolayer model are very useful to propose an adsorption mechanism. Three cases are possible concerning the value of $\mathrm{n}$; It can be less than 0.5 , $0.5<\mathrm{n}<1$, and the last case $\mathrm{n}>1$. In the case where $0.5<\mathrm{n}<1$, the molecules of the solute can orient themselves on the surface of the adsorbate in two different ways, parallel and non-parallel with a certain centering for each type of orientation. The case where $\mathrm{n}<0.5$ corresponds to an adsorption where the molecules of the solute are oriented in a parallel way on the surface of the adsorbent. $\mathrm{n}>$ 1 indicates that the molecules are anchored vertically on a site, leading to an aggregation. It is noted that the anchoring of the molecule on the adsorbent depends on its size, its structure and also on its charge. The results of calculations of the various anchoring parameters are summarized in the Table 7. It should be observed from the Table 7 that at a temperature equal to $20^{\circ} \mathrm{C}$ the value of $\mathrm{n}$ was $=1.775$, namely between $\mathrm{n}=1$ (only one molecule is anchored at one site) and $\mathrm{n}=2$ (two molecules are anchored at one site). The following Eq. (6) was considered to measure the percentage of MB molecules with a mono anchorage (noted with X), and with two anchorage (noted with (1-X)).

$\mathrm{n}=\mathrm{X} \times 1+(1-\mathrm{X}) \times 2$

For the first $\mathrm{n}\left(\mathrm{n}_{1}=1.775\right)$, it was found that $22.5 \%$ of the sites (type one) were occupied by one molecule, and the rest of the sites were occupied by two molecules (77.5\%) [56]. Regarding the second $n\left(n_{2}=1.957\right)$ at $293 \mathrm{~K}$, it was found that $4.3 \%$ of the sites (type two) were occupied by one molecule, while the majority of the sites were occupied by two molecules (95.7\%).

The values of $\mathrm{n}_{1}$ increased from 1.775 for $20^{\circ} \mathrm{C}$ to $\mathrm{n}_{1}=3.553{ }^{\circ} \mathrm{C}$ for $30^{\circ} \mathrm{C}$, showing that the arrangement of the MB molecules on the surface of the adsorbent was affected by the temperature. It can easily be concluded that when the temperature increases, the number of molecules adsorbed 
per site decreases. On the contrary, the $\mathrm{n}_{2}$ values decreased from 1.956 for $20^{\circ} \mathrm{C}$ to $\mathrm{n}_{2}=1.025$ for $30{ }^{\circ} \mathrm{C}$. This shows that the percentage of sites (type two) that anchor two molecules decreased from $95.7 \%$ to $2.5 \%$. This can possibly be due to the increase in temperature that eliminated the bindings between the MB dye molecules. It should be noted that this observation deserves further study concerning the different functions existing on the surface of the adsorbent material capable of creating an interaction or anchoring, since the sites $n_{1}$ and $n_{2}$ are not physically defined, which complicates the conclusion. It can be noticed that $n_{1}$ increases and $n_{2}$ decreases when the temperature increases, showing an exchange or a compromise between the sites $\mathrm{n}_{1}$ and $\mathrm{n}_{2}$ concerning the adsorbed molecules when the temperature varied.

Concerning the Nmi parameter, it is defined as the number of receptor sites occupied at saturation, with $\mathrm{Nm} 1$ the number of receptor of the type one of occupied sites and Nm2 is the number of receptor of the type two of occupied sites. From Table 7, it can be noted that the increase in temperature caused a decrease for the first type of density $\mathrm{Nm} 1$ and an increase for the second type Nm2. Note that each density for each different site varied with an inverse trend compared to the number of MB products captured. In fact, the reduction in the number of MB molecules captured per site created free space for the PACK biosorbent that contribute to the adsorption producing an increase in the number of anchorages $\left(n^{\prime}=1 / n\right)$, followed by an increase in density Nmi.

\subsection{Study of the effect of the parameters governing adsorption}

\subsubsection{The effect of $\mathbf{p H}$}

In Figure 8, the influence of the initial pH is shown. It can be observed a very low adsorbed quantity for a very low $\mathrm{pH}$ range compared to the $\mathrm{pHpzc}$ and this may be due to the repulsion force between the positively charged material and the MB cationic dye. The adsorbed quantity increased as the 
$\mathrm{pH}$ increased towards the pHpzc until the maximum adsorbed quantity was obtained at the natural $\mathrm{pH}$, 6.5. This increase can be explained by the increase in the negative charges on the PACK surface due to the increase in $\mathrm{pH}$. The availability of negative charges on the PACK biosorbent surface favors the adsorption of the cationic dye MB [38]. Above the natural $\mathrm{pH}$, there was a color change of the solution from blue to green color, associated with a maximum wavelength change from $664 \mathrm{~nm}$ to $570 \mathrm{~nm}$ with emergence continues of the wavelength of the MB color. This color alteration can be attributed to secondary chemical reactions between the MB dye and the PACK modifying material in a range of $\mathrm{pH}$ above the natural $\mathrm{pH}$, which caused the changes in the $\mathrm{MB}$ dye's ionic character.

\subsubsection{The effect of the temperature}

$25 \mathrm{mg}$ of PACK adsorbent was added to $50 \mathrm{ml}$ of a MB solution at a concentration of $800 \mathrm{mg} / \mathrm{L}$ at the natural $\mathrm{pH}$. The suspension was stirred for the equilibrium time. The protocol was repeated at 20, 30 and $40{ }^{\circ} \mathrm{C}$. Figure 6 showed that the adsorption capacity increased with increasing temperature. As the temperature increases, it is usual for the viscosity of a solution to decrease, thus increased the mobility of the adsorbate as well, and thus an increase in the penetration of the MB molecules through the pores of the PACK is expected. At the same time, there could be more chemical interaction between the adsorbate and the surface of the bisorbent [57, 58].Tan et al [59] reported a similar pattern in the adsorption of MB on activated oil palm fiber carbon.

\subsubsection{The humic acid effect}

According to the results obtained (Figure not shown) and compared to the maximum quantity adsorbed for a concentration of $400 \mathrm{mg} / \mathrm{L}$ of $\mathrm{MB}$ in the absence of humic acid (total elimination), there was a stable negative effect for each addition of different amounts of humic acid. This result 
can be explained by the adsorption competition between the cations of the humic acid in the solution and the MB dye on the PACK material. However, Figure 9 demonstrates the ability of the PACK to maintain high MB removal at high ionic strength. Therefore, Textile wastewater treatment, which may contains such components, may be effective by this material.

\subsubsection{The Effect of the biosorbent dose on biosorption}

The effect of the adsorbent dosage on the adsorption capacity of BM dye is displayed in Figure 9. It showed a reduction in the adsorption capacity per unit mass of the adsorbent for a rise in the mass of the adsorbent, which was however accompanied by an increase in the rate of biosorption, leading to a greater removal of the pollutant. This can be due to an increase in the available surface area and an increase in the number of active sites on the surface of the PACK material [8].

\subsection{Desorption study}

In order to determine the recovery rate of the PACK product, the desorption of the adsorbed MB dye after adsorption was carried out in three different solutions, $0.1 \mathrm{M} \mathrm{HCl}, 0.1 \mathrm{M} \mathrm{NaOH}$, and 0.1

$\mathrm{M}$ ethanol; the corresponding results are shown in the Figure 10. For this purpose, after MB adsorption experiments at an initial concentration of $400 \mathrm{mg} / \mathrm{L}$, the solid phase (PACK) was separated from the solution and placed in $\mathrm{HCl}, \mathrm{NaOH}$, or ethanol and stirred until reached the equilibrium time for the desorption. At equilibrium the quantities of MB desorbed in the three solutions were determined. Using $\mathrm{HCl}$, the amount of desorbed dye was recovered at the highest rate $(52.88 \%)$, if compared to the two other solutions, $\mathrm{NaOH}$ and ethanol; it is probably related to the breakage of the physical bonds (van der Waals) between the MB dye and the PACK product at acidic pH. However, nearly half of the adsorbed dye was not retrieved. This may be due to the loss of absorbent material during the transition from the absorption process to the desorption 
process and also to the possibility that the dye which diffused into the particle or chemically bound was not fully recovered [37].

\subsection{Proposed mechanism of adsorption of MB onto the PACK material}

Based on the findings of the isoelectric point, the $\mathrm{pH}$ effect, the FT-IR analysis and the results of the D.K isotherm model the following assumptions can be drawn. The adsorption mechanism of MB onto the PACK can be supposed to be globally guided by electrostatic interactions (physical adsorption) between the adsorbent which becomes negatively charged, each time the $\mathrm{pH}$ is switched from acidic to its pHpzc, and the positively charged dye; also due to weak hydrogen bonds between the nitrogen atoms present in the molecules of MB and the hydrogen atoms in the functional groups available on the surface of the adsorbent, as well as due to cations exchange. In addition and according to the analysis result of the FTIR, a $\pi-\pi$ interaction can also occur in the process of biosorption MB_PACK. The MB dye is a polycyclic aromatic compound containing therefore several benzene rings; benzene rings were also confirmed in the biosorbent through FTIR analysis which revealed the presence of a $\mathrm{C}=\mathrm{C}$ aromatic stretch. In addition, since these benzene rings are electron-rich areas, they can produce a donor-acceptor stacking interactions between MB and PACK. The description of the MB biosorption process is shown in the Figure 11.

\subsection{Comparison of the MB adsorption capacity on some adsorbents}

The comparison of the maximum adsorption capacity of some adsorbents on methylene blue is displayed in Table 7. It should be noted that the adsorption capacity of modified powder of Acorus calamus on MB appeared to be greater than that of other adsorbents, including activated carbon. The potential of PACK, an easily available and low-cost material, to be used as an alternative biosorbent material for the removal of a dye, $\mathrm{MB}$, from aqueous solutions was therefore confirmed. 
Table 8. Comparison of maximum monolayer adsorption of MB on some adsorbents in the literature

\begin{tabular}{lll}
\hline Adsorbent & Adsorption Capacity (mg/g) & References \\
\hline Bentonite (alginate beads) & 2024 & {$[60]$} \\
PACK & 1500 & This study \\
Ziziphus jujuba stones (BZJS1) (alginate beads) & 737.13 & {$[39]$} \\
pectin from orange industry residues (alginate beads & 398.40 & {$[34]$} \\
graphene oxide & 357.14 & {$[61]$} \\
$\mathrm{OP}_{-} \mathrm{H}_{3} \mathrm{PO}_{4}$ & 307.63 & {$[38]$} \\
Palm fiber- activated carbon & 278 & {$[59]$} \\
Activated carbon from Mangosteen fruit peel & 230 & {$[62]$} \\
Wild carob-activated carbon & 218 & {$[63]$} \\
Chitosan flakes-activated carbon & 144 & {$[64]$} \\
Fe $_{3} \mathrm{O}_{4}$ particle & 20.40 & {$[65]$} \\
\hline
\end{tabular}

\subsubsection{Thermodynamic analysis}

Thermodynamic parameters reflect the possibility and the spontaneity of a biosorption process.

Parameters such as the free energy change $(\Delta \mathrm{G})$, the enthalpy change $(\Delta \mathrm{H})$ and the entropy change $(\Delta \mathrm{S})$ can be estimated from the variations of the equilibrium constants with the temperature.

The free enthalpy change of a biosorption reaction is given using Eq.9 as reported by Milonjic [66]:

$\Delta \mathrm{G}^{\circ}=-\mathrm{RT} \ln (\rho \mathrm{Kc})$

Where $\Delta \mathrm{G}^{\circ}$ is the free energy change $\left(\mathrm{kJ} \cdot \mathrm{mol}^{-1}\right)$, $\mathrm{R}$ the universal gas constant $\left(8.31 \mathrm{~J} \cdot \mathrm{mol}^{-1} \mathrm{~K}^{-1}\right), \mathrm{T}$ is the absolute temperature (K), Kc the thermodynamic equilibrium constant $\left(\mathrm{L} \cdot \mathrm{g}^{-1}\right)$ and $\rho$ the water density (g.L $\left.\mathrm{L}^{-1}\right)$. 
$\Delta \mathrm{H}^{\circ}$ and $\Delta \mathrm{S}^{\circ}$ values of the biosorption mechanism were calculated from Van't Hoff Eqs.10 and 11:

$\ln \left(\rho \mathrm{K}_{\mathrm{C}}\right)=-\frac{\Delta \mathrm{H}^{\mathrm{o}}}{\mathrm{RT}}+\frac{\Delta \mathrm{S}^{\mathrm{o}}}{\mathrm{R}}$

$\mathrm{K}_{\mathrm{C}}=\frac{\mathrm{Q}_{\mathrm{e}}}{\mathrm{C}_{\mathrm{e}}}$

$\Delta \mathrm{H}$ and $\Delta \mathrm{S}$ can be then deduced from the slope $(\Delta \mathrm{H} / \mathrm{R})$ and the intercept $(\Delta \mathrm{S} / \mathrm{R})$ of the plot of $\ln \left(\rho K_{C}\right)$ versus $1 / \mathrm{T}$.

In general, change in free energy values between -20 and $0 \mathrm{~kJ} \mathrm{~mol}^{-1}$ is reported for physisorption, while these values are in a range of -400 to $-80 \mathrm{~kJ} \mathrm{~mol}^{-1}$ for chemisorption processes $[63,66]$.

Table 9 gives the calculation of the thermodynamic parameters. The value obtained for the free energy was about $-20 \mathrm{KJ} / \mathrm{mol}$ for our material in the range of temperature from 20 to $40^{\circ} \mathrm{C}$ indicating that adsorption took place physically [63]. This result confirms that found with the Dubinin-Radushkevich (D-R) model. Increased randomness at the interface of the solid solution during MB biosorption on the biosorbent was demonstrated by the positive value of the entropy change.

Table 9: Calculation of the thermodynamic parameters

\begin{tabular}{lllll}
\hline Température (K) & Kc (L/g) & $\Delta H^{\mathbf{0}}(\mathbf{K J} / \mathbf{m o l})$. & $\Delta \boldsymbol{S}^{\mathbf{0}}(\mathbf{J} / \mathbf{m o l . K})$ & $\Delta G^{\mathbf{0}}(\mathbf{K J} / \mathbf{m o l})$. \\
\hline 293 & 6.36 & 54.703 & 259.72 & -21.32 \\
303 & 14.60 & & & -24.14 \\
313 & 26.65 & & -26.65 \\
\hline
\end{tabular}




\section{Conclusion}

New material was obtained by physical treatment of a low cost and abundant biosorbent, powder of Acorus calamus, with $\mathrm{H}_{2} \mathrm{SO}_{4}$ and $\mathrm{KMnO}_{4}$, denoted by PACK material.This material had a high maximum experimental capacity, 1285.34 and $1528.02 \mathrm{mg} / \mathrm{g}$ at $20^{\circ} \mathrm{C}$ and $30^{\circ} \mathrm{C}$, respectively. Isotherm models with two and three parameters, namely Langmuir, Freundlich, DubininRadushkevich (D-R), Redlich-Peterson and Sips were applied to fit experimental data. RedlichPeterson isotherm indicated better fit compared to the Langmuir, the Freundlich and the Sips isotherm models. According to the results of the kinetic modeling of MB adsorption onto the PACK material, the pseudo- $\mathrm{n}^{\text {th }}$ order model led to a better adjustment of the experimental results, if compared to both the pseudo-first and pseudo-second-order kinetics models. As per the $\mathrm{R}^{2}$ values obtained from the simulation of the results with the three advanced models, monolayer singleenergy, monolayer two-energy and double-layer two-energy models as statistical physics models, the two-energy monolayer model led to the best result of the processes of MB adsorption onto the PACK material. From this, it can be assumed that the adsorption of MB onto PACK occurred on two different sites of energy (type one and two); each site can interact with a variable number of MB molecules (n), n1 interact with type one and n2 with type two.

Regarding desorption, the PACK product gives a slightly low recovery rate with a percentage of around 53\% and this can be marked as a point of disadvantage for the material. But according to this study, the promising potential of the PACK material, as very abundant material, easily obtainable and renewable, for removing basic dyes from aqueous solutions was demonstrated. 


\section{Acknowledgements}

The authors would like to thank the MESRS and the DGRSDT (Ministère de l'Enseignement Supérieur et de la Recherche Scientifique et la Direction Générale de la Recherche Scientifique et du Développement Technologique- Algérie) for their Financial support. 


\section{Reference}

1. Novel activated carbon prepared from an agricultural waste, Stipa tenacissima, based on $\mathrm{ZnCl} 2$ activation - characterization and application to the removal of methylene blue: Desalination and Water Treatment: Vol 57, No 50. https:/www.tandfonline.com/doi/abs/10.1080/19443994.2015.1137231. Accessed 9 Mar 2020

2. Robinson T, McMullan G, Marchant R, Nigam P (2001) Remediation of dyes in textile effluent: a critical review on current treatment technologies with a proposed alternative. Bioresource Technology 77:247-255. https://doi.org/10.1016/S0960-8524(00)00080-8

3. Soloman PA, Basha CA, Velan M, et al (2009) Electrochemical Degradation of Remazol Black B Dye Effluent. Clean Soil Air Water 37:889-900. https://doi.org/10.1002/clen.200900055

4. Miyah Y, Lahrichi A, Idrissi M, et al (2017) Assessment of adsorption kinetics for removal potential of Crystal Violet dye from aqueous solutions using Moroccan pyrophyllite. Journal of the Association of Arab Universities for Basic and Applied Sciences 23:20-28. https://doi.org/10.1016/j.jaubas.2016.06.001

5. Juang RS, Wu FC, Tseng RL (1997) The Ability of Activated Clay for the Adsorption of Dyes from Aqueous Solutions. Environmental Technology 18:525-531. https://doi.org/10.1080/09593331808616568 
6. Rangabhashiyam S, Anu N, Selvaraju N (2013) Sequestration of dye from textile industry wastewater using agricultural waste products as adsorbents. Journal of Environmental Chemical Engineering 1:629-641. https://doi.org/10.1016/j.jece.2013.07.014

7. Ahmed MJ, Dhedan SK (2012) Equilibrium isotherms and kinetics modeling of methylene blue adsorption on agricultural wastes-based activated carbons. Fluid Phase Equilibria 317:914. https://doi.org/10.1016/j.fluid.2011.12.026

8. Şenol ZM (2020) Effective biosorption of Allura red dye from aqueous solutions by the driedlichen ( Pseudoevernia furfuracea ) biomass. International Journal of Environmental Analytical Chemistry 1-15. https://doi.org/10.1080/03067319.2020.1785439

9. Badr S, Ashmawy AA, El Sherif I, Moghazy R (2016) Non-conventional low-cost biosorbents for adsorption and desorption of heavy metals. Research Journal of Pharmaceutical, Biological and Chemical Sciences 7:3110-3122

10. Berrios M, Martín MÁ, Martín A (2012) Treatment of pollutants in wastewater: Adsorption of methylene blue onto olive-based activated carbon. Journal of Industrial and Engineering Chemistry 18:780-784. https://doi.org/10.1016/j.jiec.2011.11.125

11. Suárez-García F, Martínez-Alonso A, Tascón JMD (2001) Porous texture of activated carbons prepared by phosphoric acid activation of apple pulp. Carbon 39:1111-1115. https://doi.org/10.1016/S0008-6223(01)00053-7

12. Ubago-Pérez R, Carrasco-Marín F, Fairén-Jiménez D, Moreno-Castilla C (2006) Granular and monolithic activated carbons from $\mathrm{KOH}$-activation of olive stones. Microporous and Mesoporous Materials 92:64-70. https://doi.org/10.1016/j.micromeso.2006.01.002 
13. Attia AA, Girgis BS, Fathy NA (2008) Removal of methylene blue by carbons derived from peach stones by H3PO4 activation: Batch and column studies. Dyes and Pigments 76:282289. https://doi.org/10.1016/j.dyepig.2006.08.039

14. El-Hendawy A-NA, Samra SE, Girgis BS (2001) Adsorption characteristics of activated carbons obtained from corncobs. Colloids and Surfaces A: Physicochemical and Engineering Aspects 180:209-221. https://doi.org/10.1016/S0927-7757(00)00682-8

15. Baquero M (2003) Activated carbons by pyrolysis of coffee bean husks in presence of phosphoric acid. Journal of Analytical and Applied Pyrolysis 70:779-784. https://doi.org/10.1016/S0165-2370(02)00180-8

16. Kyzas GZ, Lazaridis NK, Mitropoulos ACh (2012) Removal of dyes from aqueous solutions with untreated coffee residues as potential low-cost adsorbents: Equilibrium, reuse and thermodynamic approach. Chemical Engineering Journal 189-190:148-159. https://doi.org/10.1016/j.cej.2012.02.045

17. Namane A, Mekarzia A, Benrachedi K, et al (2005) Determination of the adsorption capacity of activated carbon made from coffee grounds by chemical activation with $\mathrm{ZnCl}$ and $\mathrm{HPO}$. Journal of Hazardous Materials 119:189-194. https://doi.org/10.1016/j.jhazmat.2004.12.006

18. Yagmur E, Ozmak M, Aktas Z (2008) A novel method for production of activated carbon from waste tea by chemical activation with microwave energy. Fuel 87:3278-3285. https://doi.org/10.1016/j.fuel.2008.05.005 
19. Valix M, Cheung WH, McKay G (2004) Preparation of activated carbon using low temperature carbonisation and physical activation of high ash raw bagasse for acid dye adsorption. Chemosphere 56:493-501. https://doi.org/10.1016/j.chemosphere.2004.04.004

20. Laine J, Calafat A, labady M (1989) Preparation and characterization of activated carbons from coconut shell impregnated with phosphoric acid. Carbon 27:191-195. https://doi.org/10.1016/0008-6223(89)90123-1

21. Önal Y (2006) Kinetics of adsorption of dyes from aqueous solution using activated carbon prepared from waste apricot. Journal of Hazardous Materials 137:1719-1728. https://doi.org/10.1016/j.jhazmat.2006.05.036

22. Patel R, Suresh S (2008) Kinetic and equilibrium studies on the biosorption of reactive black 5 dye by Aspergillus foetidus. Bioresource Technology 99:51-58. https://doi.org/10.1016/j.biortech.2006.12.003

23. Aksu Z (2005) Application of biosorption for the removal of organic pollutants: a review. Process Biochemistry 40:997-1026. https://doi.org/10.1016/j.procbio.2004.04.008

24. Dotto GL, Pinto LAA (2011) Adsorption of food dyes onto chitosan: Optimization process $\begin{array}{llll}\text { and } & \text { kinetic. } & \text { Carbohydrate }\end{array}$ https://doi.org/10.1016/j.carbpol.2010.11.028

25. Dotto GL, Vieira MLG, Esquerdo VM, Pinto LAA (2013) Equilibrium and thermodynamics of azo dyes biosorption onto Spirulina platensis. Braz J Chem Eng 30:13-21. https://doi.org/10.1590/S0104-66322013000100003 
26. Kaur H, Thakur A (2014) Adsorption of Congo red dye from aqueous solution onto Ash of Cassia Fistula seeds: Kinetic and Thermodynamic Studies. chemical science review and letters 3:159-169

27. Low cost adsorbents from agricultural waste for removal of dyes - Ramaraju - 2014 Environmental Progress \&amp; Sustainable Energy - Wiley Online Library. https://aiche.onlinelibrary.wiley.com/doi/full/10.1002/ep.11742. Accessed 6 Nov 2020

28. Ramakrishnaiah C (2014) Removal of Colour from Textile Effluent by Adsorption Using Low Cost Adsorbents. IRJPAC 4:568-577. https://doi.org/10.9734/IRJPAC/2014/5772

29. Chebli D, Bouguettoucha A, Mekhalef T, et al (2015) Valorization of an agricultural waste, Stipa tenassicima fibers, by biosorption of an anionic azo dye, Congo red. Desalination and Water Treatment 54:245-254. https://doi.org/10.1080/19443994.2014.880154

30. Bouguettoucha A, Chebli D, Mekhalef T, Noui A, Amrane A (2014) The use of a forest waste biomass, cone of Pinus brutia for the removal of an anionic azo dye Congo red from aqueous medium. https://www.researchgate.net/publication/264554082

_ 31. Reffas A, Bouguettoucha A, Chebli D, Amrane A (2016) Adsorption of ethyl violet dye in aqueous solution by forest wastes, wild carob. Desalination and Water Treatment 57:98599870. https://doi.org/10.1080/19443994.2015.1031707

32. Chebli D, Bouguettoucha A, Reffas A, et al (2016) Removal of the anionic dye Biebrich scarlet from water by adsorption to calcined and non-calcined Mg-Al layered double hydroxides. Desalination and Water Treatment 57:22061-22073. https://doi.org/10.1080/19443994.2015.1128365 
33. Gündüz F, Bayrak B (2017) Biosorption of malachite green from an aqueous solution using pomegranate peel: Equilibrium modelling, kinetic and thermodynamic studies. Journal of Molecular Liquids 243:790-798. https://doi.org/10.1016/j.molliq.2017.08.095

34. Kebaili M, Djellali S, Radjai M, et al (2018) Valorization of orange industry residues to form a natural coagulant and adsorbent. Journal of Industrial and Engineering Chemistry 64:292299. https://doi.org/10.1016/j.jiec.2018.03.027

35. HASDEMIR ZM, ŞIMŞEK S (2018) Removal of cationic dye in aquatic medium by using a new composite material. Cumhuriyet Science Journal 39:181-191

36. Patel RK, Kumar S, Chawla AK, et al (2019) Elimination of Fluoride, Arsenic, and Nitrate from Water Through Adsorption onto Nano-adsorbent: A Review. CNANO 15:557-575. https://doi.org/10.2174/1573413715666190101113651

37. Şenol ZM, Gürsoy N, Şimşek S, et al (2020) Removal of food dyes from aqueous solution by chitosan-vermiculite beads. International Journal of Biological Macromolecules 148:635646. https://doi.org/10.1016/j.jibiomac.2020.01.166

38. Guediri A, Bouguettoucha A, Chebli D, et al (2020) Molecular dynamic simulation and DFT computational studies on the adsorption performances of methylene blue in aqueous solutions by orange peel-modified phosphoric acid. Journal of Molecular Structure 1202:127290. https://doi.org/10.1016/j.molstruc.2019.127290

39. Guediri A, Bouguettoucha A, Chebli D, Amrane A (2020) The use of encapsulation as a proposed solution to avoid problems encountered with conventional materials in powder 
form: Application in methylene blue removal from aqueous solutions. Journal of Molecular Liquids 316:113841. https://doi.org/10.1016/j.molliq.2020.113841

40. Lin J, Wang L (2009) Comparison between linear and non-linear forms of pseudo-first-order and pseudo-second-order adsorption kinetic models for the removal of methylene blue by activated carbon. Front Environ Sci Eng China 3:320-324. https://doi.org/10.1007/s11783009-0030-7

41. Simonin J-P (2016) On the comparison of pseudo-first order and pseudo-second order rate laws in the modeling of adsorption kinetics. Chemical Engineering Journal 300:254-263. https://doi.org/10.1016/j.cej.2016.04.079

42. Oladipo AA, Gazi M (2014) Enhanced removal of crystal violet by low cost alginate/acid activated bentonite composite beads: Optimization and modelling using non-linear regression technique. Journal of Water Process Engineering 2:43-52. https://doi.org/10.1016/j.jwpe.2014.04.007

43. Tseng R-L, Wu P-H, Wu F-C, Juang R-S (2014) A convenient method to determine kinetic parameters of adsorption processes by nonlinear regression of pseudo-nth-order equation. Chemical Engineering Journal 237:153-161. https://doi.org/10.1016/j.cej.2013.10.013

44. Eastoe J, Dalton JS (2000) Dynamic surface tension and adsorption mechanisms of surfactants at the air-water interface. Advances in Colloid and Interface Science 85:103-144. https://doi.org/10.1016/S0001-8686(99)00017-2

45. Sellaoui L, Bouzid M, Duclaux L, et al (2016) Binary adsorption isotherms of two ionic liquids and ibuprofen on an activated carbon cloth: simulation and interpretations using 
statistical and COSMO-RS models. RSC Adv 6:67701-67714. https://doi.org/10.1039/C6RA03405E

46. Bouaziz N, Ben Manaa M, Aouaini F, Ben Lamine A (2019) Investigation of hydrogen adsorption on zeolites A, X and Y using statistical physics formalism. Materials Chemistry and Physics 225:111-121. https://doi.org/10.1016/j.matchemphys.2018.12.024

47. Sellaoui L, Dotto GL, Lamine AB, Erto A (2017) Interpretation of single and competitive adsorption of cadmium and zinc on activated carbon using monolayer and exclusive extended monolayer models. Environ Sci Pollut Res 24:19902-19908. https://doi.org/10.1007/s11356017-9562-8

48. Sellaoui L, Edi Soetaredjo F, Ismadji S, et al (2017) New insights into single-compound and binary adsorption of copper and lead ions on a treated sea mango shell: experimental and theoretical studies. Phys Chem Chem Phys 19:25927-25937. https://doi.org/10.1039/C7CP03770H

49. Lawal IA, Lawal MM, Akpotu SO, et al (2018) Theoretical and experimental adsorption studies of sulfamethoxazole and ketoprofen on synthesized ionic liquids modified CNTs. $\begin{array}{llll}\text { Ecotoxicology } \quad \text { and } & \text { Environmental }\end{array}$ https://doi.org/10.1016/j.ecoenv.2018.06.019

50. Sellaoui L, Guedidi H, Knani S, et al (2015) Application of statistical physics formalism to the modeling of adsorption isotherms of ibuprofen on activated carbon. Fluid Phase Equilibria 387:103-110. https://doi.org/10.1016/j.fluid.2014.12.018 
51. Silva LS, Lima LCB, Ferreira FJL, et al (2015) Sorption of the anionic reactive red RB dye in cellulose: Assessment of kinetic, thermodynamic, and equilibrium data. Open Chemistry 13:. https://doi.org/10.1515/chem-2015-0079

52. El-Sikaily A, El Nemr A, Khaled A (2011) Copper sorption onto dried red alga Pterocladia capillacea and its activated carbon. Chemical Engineering Journal 168:707-714. https://doi.org/10.1016/j.cej.2011.01.064

53. Khelifa A (2001) Adsorption de CO2 par des zeolithes X echangees par des cations bivalents. Annales de Chimie Science des Matériaux 26:55-66. https://doi.org/10.1016/S01519107(01)80046-5

54. Şenol ZM, Gül ÜD, Gürkan R (2020) Bio-sorption of bisphenol a by the dried- and inactivated-lichen (Pseudoevernia furfuracea) biomass from aqueous solutions. J Environ Health Sci Engineer. https://doi.org/10.1007/s40201-020-00508-6

55. Eren E (2008) Removal of copper ions by modified Unye clay, Turkey. Journal of Hazardous Materials 159:235-244. https://doi.org/10.1016/j.jhazmat.2008.02.035

56. Aouaini F, Souhail B, Khemiri N, et al (2019) Study of the $\mathrm{CO}_{2}$ adsorption isotherms on El Hicha clay by statistical physics treatment: microscopic and macroscopic investigation. Separation Science and 54:2577-2588. https://doi.org/10.1080/01496395.2018.1548487

57. Khattri SD, Singh MK (2009) Removal of malachite green from dye wastewater using neem sawdust by adsorption. Journal of Hazardous Materials 167:1089-1094. https://doi.org/10.1016/j.jhazmat.2009.01.101 
58. Cherifi H, Fatiha B, Salah H (2013) Kinetic studies on the adsorption of methylene blue onto vegetal fiber activated carbons. Applied Surface Science 282:52-59. https://doi.org/10.1016/j.apsusc.2013.05.031

59. Tan IAW, Hameed BH, Ahmad AL (2007) Equilibrium and kinetic studies on basic dye adsorption by oil palm fibre activated carbon. Chemical Engineering Journal 127:111-119. https://doi.org/10.1016/j.cej.2006.09.010

60. Harrache Z, Abbas M, Aksil T, Trari M (2019) Thermodynamic and kinetics studies on adsorption of Indigo Carmine from aqueous solution by activated carbon. Microchemical Journal 144:180-189. https://doi.org/10.1016/j.microc.2018.09.004

61. Rahmi, Ishmaturrahmi, Mustafa I (2019) Methylene blue removal from water using H2SO4 crosslinked magnetic chitosan nanocomposite beads. Microchemical Journal 144:397-402. https://doi.org/10.1016/j.microc.2018.09.032

62. Liu X, Cui B, Liu S, Ma Q (2019) Methylene Blue Removal by Graphene Oxide/Alginate Gel Beads. Fibers Polym 20:1666-1672. https://doi.org/10.1007/s12221-019-9011-z

63. Bounaas M, Bouguettoucha A, Chebli D, et al (2020) Role of the Wild Carob as Biosorbent and as Precursor of a New High-Surface-Area Activated Carbon for the Adsorption of Methylene Blue. Arab J Sci Eng. https://doi.org/10.1007/s13369-020-04739-5

64. Marrakchi F, Ahmed MJ, Khanday WA, et al (2017) Mesoporous-activated carbon prepared from chitosan flakes via single-step sodium hydroxide activation for the adsorption of methylene blue. International Journal of Biological Macromolecules 98:233-239. https://doi.org/10.1016/j.ijbiomac.2017.01.119 
65. Ravi, Pandey LM (2019) Enhanced adsorption capacity of designed bentonite and alginate beads for the effective removal of methylene blue. Applied Clay Science 169:102-111. https://doi.org/10.1016/j.clay.2018.12.019

66. Milonjic S (2007) A consideration of the correct calculation of thermodynamic parameters of adsorption. J Serb Chem Soc 72:1363-1367. https://doi.org/10.2298/JSC0712363M 
Table 1: Chemical properties of Methylene Blue.

\begin{tabular}{llllll}
\hline Dye & Classification & $\lambda_{\max }(\mathrm{nm})$ & Empirical formula & $\begin{array}{l}\text { Formula weight } \\
\left(\text { g. mol }^{-1}\right)\end{array}$ & $\begin{array}{l}\text { Solubility } \\
\text { in water }\end{array}$ \\
\hline Methylene & Cationicdye & 664 & $\mathrm{C}_{16} \mathrm{H}_{18} \mathrm{~N}_{3} \mathrm{ClS}$ & 320 & $>$ 50g. $\mathrm{L}^{-1}$ \\
Blue & & & & \\
\hline
\end{tabular}

Table 2: Adsorption kinetics models used in this work and their parameters.

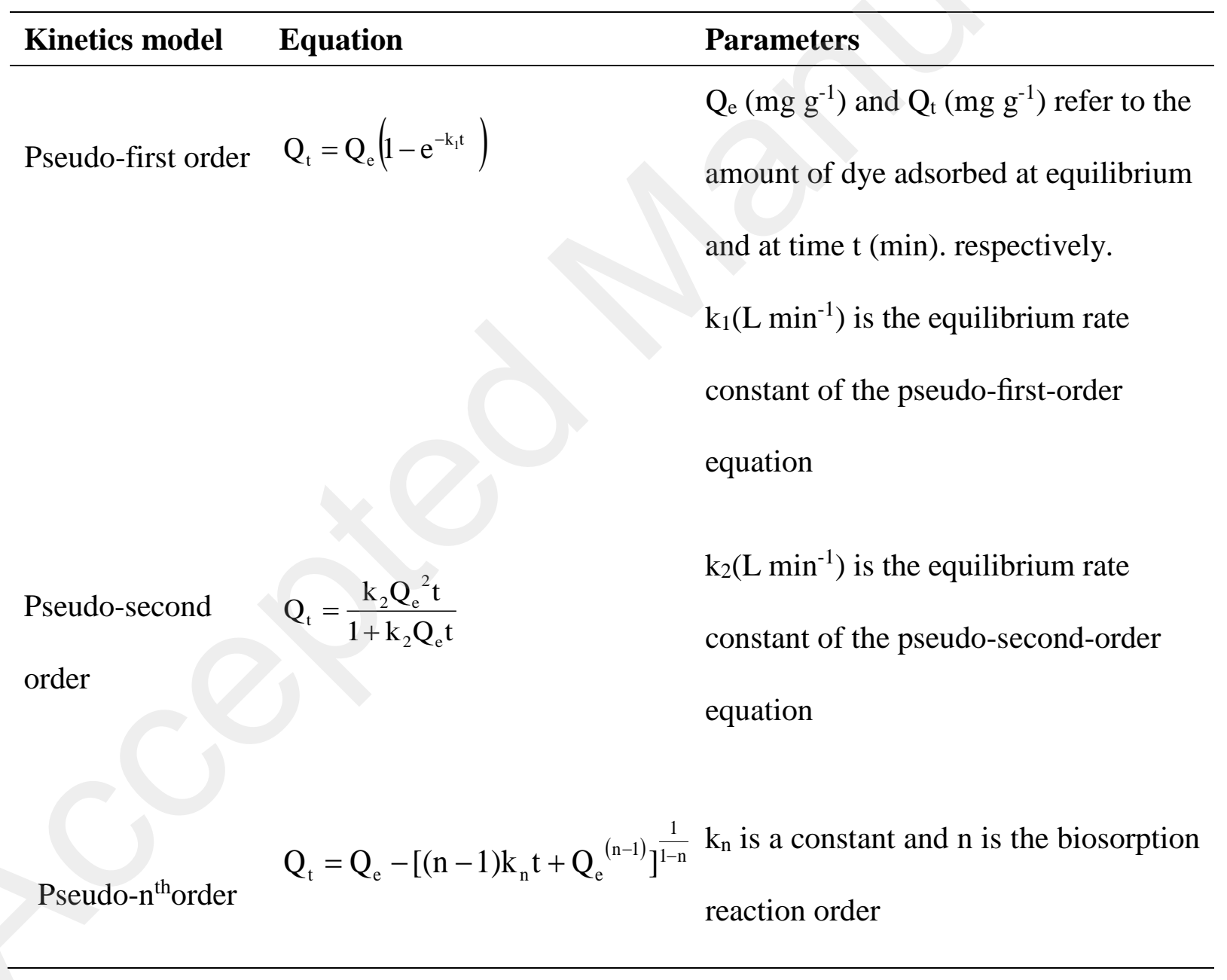


Table 3: Adsorption isotherm models adopted in this work and their parameters.

\begin{tabular}{|c|c|c|}
\hline Isotherme & Equation & Parameters \\
\hline Langmuir & $\frac{\mathrm{Q}_{\mathrm{e}}}{\mathrm{Q}_{\mathrm{m}}}=\frac{\mathrm{K}_{\mathrm{L}} \mathrm{C}_{\mathrm{e}}}{1+\mathrm{K}_{\mathrm{L}} \mathrm{C}_{\mathrm{e}}}$ & $\begin{array}{l}\mathrm{Q}_{\mathrm{e}}\left(\mathrm{mg} \mathrm{g}^{-1}\right) \text { is the amount of MB adsorbed per } \\
\text { unit mass of adsorbent } \\
\mathrm{C}_{\mathrm{e}}\left(\mathrm{mg} \mathrm{L}^{-1}\right) \text { the equilibrium dye concentration in } \\
\text { solution } \\
\mathrm{Q}_{\mathrm{m}}\left(\mathrm{mg} \mathrm{g}^{-1}\right) \text { the monolayer capacity of the } \\
\text { adsorbent } \\
\mathrm{K}_{\mathrm{L}} \text { the Langmuir constant }\end{array}$ \\
\hline Freundlich & $\mathrm{Q}_{\mathrm{e}}=\mathrm{K}_{\mathrm{F}} \mathrm{C}_{\mathrm{e}}^{1 / \mathrm{n}}$ & $\begin{array}{l}\mathrm{K}_{\mathrm{F}} \text { and } \mathrm{n}^{-1} \text { are empirical constants indicative of } \\
\text { sorption capacity and sorption intensity. } \\
\text { respectively }\end{array}$ \\
\hline Sips & $\frac{\mathrm{Q}_{\mathrm{e}}}{\mathrm{Q}_{\mathrm{m}}}=\frac{\left(\mathrm{K}_{\mathrm{s}} \mathrm{C}_{\mathrm{e}}\right)^{m}}{1+\left(\mathrm{K}_{\mathrm{s}} \mathrm{C}_{\mathrm{e}}\right)^{m}}$ & $\begin{array}{l}\mathrm{K}_{\mathrm{s}} \mathrm{i}\left(\mathrm{L} \mathrm{mg}^{-1}\right) \text { the Sips constant } \\
\mathrm{m} \text { the exponent of the Sips model }\end{array}$ \\
\hline Redlich-Peterson & $\mathrm{Q}_{\mathrm{e}}=\frac{\mathrm{k}_{\mathrm{R}} \mathrm{C}_{\mathrm{e}}}{1+\alpha_{\mathrm{R}} \mathrm{C}_{\mathrm{e}}^{\beta_{\mathrm{R}}}}$ & $\begin{array}{l}\mathrm{k}_{\mathrm{R}}\left(\mathrm{L} \mathrm{g}^{1}\right) \text { is the Redlich-Peterson }(\mathrm{R}-\mathrm{P}) \\
\text { isotherm constant } \\
\alpha_{\mathrm{R}}\left(\mathrm{L} \mathrm{mg}^{-1}\right) \text { is also having a constant unit of } \\
\beta_{\mathrm{R}} \text { is an exponent }\end{array}$ \\
\hline \multirow{3}{*}{$\begin{array}{l}\text { Dubinin- } \\
\text { Radushkevich }\end{array}$} & \multirow[t]{3}{*}{$\mathrm{Qe}=\mathrm{QDR}_{\mathrm{DR}} \exp \left(-\mathrm{k}_{\mathrm{DR}} \varepsilon^{\wedge^{2}}\right)$} & QDR is capacity of the adsorbent (mg/g) \\
\hline & & $\mathrm{K}_{\mathrm{DR}}$ is the activity coefficient $\left(\mathrm{mol}^{2} \mathrm{KJ}^{2}\right)$ \\
\hline & & $\begin{array}{l}\varepsilon \text { stands for constant related to the biosorption } \\
\text { energy }\end{array}$ \\
\hline
\end{tabular}


Table 4: Grand canonical partition function and equation of the three models of statistical physics

\begin{tabular}{|c|c|c|}
\hline Model & Grand canonical partition function & Equation \\
\hline 1 & $z_{g c}=\sum_{N_{i}=0.1}^{P} 1+e^{\beta(\varepsilon+\mu) N_{i}}$ & $\mathrm{Q}=\frac{\mathrm{n} \cdot \mathrm{Nm}}{1+\left(\frac{\mathrm{C}_{1 / 2}}{\mathrm{Ce}}\right)^{\mathrm{n}}}$ \\
\hline 2 & $\begin{aligned} z_{g c}=\left(1+e^{\beta\left(\varepsilon_{1}+\mu\right)}\right)^{N_{1 m}} & \\
& +\left(1+e^{\beta\left(\varepsilon_{1}+\mu\right)}\right)^{N_{2 m}}\end{aligned}$ & $\mathrm{Q}=\frac{\mathrm{n} 1 \cdot \mathrm{Nm} 1 .}{1+\left(\frac{\mathrm{C} 1}{\mathrm{Ce}}\right)^{\mathrm{n} 1}}+\frac{\mathrm{n} 2 \cdot \mathrm{Nm} 2}{1+\left(\frac{\mathrm{C} 2}{\mathrm{Ce}}\right)^{\mathrm{n} 2}}$ \\
\hline 3 & $z_{g c}=\sum_{1} 1+e^{\beta(\varepsilon+\mu)}+e^{2 \beta(\varepsilon+\mu) N_{m}}$ & $Q=n \cdot N_{M} \cdot \frac{\left(\frac{C}{C 1}\right)^{n}+2 \cdot\left(\frac{C}{C 2}\right)^{2 n}}{1+\left(\frac{C}{C 1}\right)^{n}+2 \cdot\left(\frac{C}{C 2}\right)^{2 n}}$ \\
\hline
\end{tabular}

Tableau 5: Kinetic parameters and correlation coefficients for nonlinear regression of PFO PSO and PNO models for the adsorption of MB onto PACK at room temperature.

\begin{tabular}{|c|c|c|c|c|}
\hline Material & Model & Parameters & 100 & 150 \\
\hline \multirow{11}{*}{ PACK } & \multirow{4}{*}{ PFO } & Qexp & 374 & 547 \\
\hline & & Qe & 368.88 & 528.05 \\
\hline & & $\mathrm{K}_{1}$ & 0.153 & 0.093 \\
\hline & & $\mathbf{R}^{2}$ & 0.994 & 0.9494 \\
\hline & \multirow{3}{*}{ PSO } & Qe & 391.46 & 572.70 \\
\hline & & $\mathrm{K}_{2} * 10^{+4}$ & 6.94 & 2.60 \\
\hline & & $\mathbf{R}^{2}$ & 0.989 & 0.986 \\
\hline & \multirow{4}{*}{ PNO } & Qe & 373.87 & 604.37 \\
\hline & & $\mathrm{k}_{\mathrm{n}}$ & 0.029 & $1.16 \mathrm{E}-05$ \\
\hline & & $\mathrm{n}$ & 1.31 & 2.50 \\
\hline & & $\mathbf{R}^{2}$ & 0.997 & 0.986 \\
\hline
\end{tabular}


Tableau 6. Langmuir. Freundlich. Sips and Redlich-Peterson (R-P) constants for the adsorption of MB onto PACK

\begin{tabular}{|c|c|c|c|c|}
\hline & & & $20^{\circ} \mathrm{C}$ & $30^{\circ} \mathrm{C}$ \\
\hline \multirow{23}{*}{ PACK } & \multirow{5}{*}{ Langmuir } & $Q_{\exp }(\mathrm{mg} / \mathrm{g})$ & 1285.34 & 1528.02 \\
\hline & & $\mathrm{Q}_{\mathrm{m}}(\mathrm{mg} / \mathrm{g})$ & 1219.23 & 1522.34 \\
\hline & & $\mathrm{K}_{\mathrm{L}}(\mathrm{L} / \mathrm{mg}) \times 10^{3}$ & 0.256 & 0.219 \\
\hline & & Ferror & 0.365 & 0.926 \\
\hline & & $\mathbf{R}^{2}$ & 0.949 & 0.992 \\
\hline & \multirow{4}{*}{ Freundlich } & $1 / n$ & 0.22 & 0.24 \\
\hline & & $\mathrm{K}_{\mathrm{F}}(\mathrm{mg} / \mathrm{g})(\mathrm{L} / \mathrm{mg})^{1 / \mathrm{n}}$ & 381.59 & 414.21 \\
\hline & & Ferror & 0.857 & 0.950 \\
\hline & & $\mathrm{R}^{2}$ & 0.843 & 0.877 \\
\hline & \multirow{6}{*}{ Sips } & $\mathrm{Q}_{\mathrm{m}}(\mathrm{mg} / \mathrm{g})$ & 1176.18 & 1502.57 \\
\hline & & $\mathrm{K}_{\mathrm{S}}(\mathrm{L} / \mathrm{mg})$ & 0.299 & 0.235 \\
\hline & & $\mathrm{m}$ & 1.26 & 1.08 \\
\hline & & Ferror & 0.471 & 0.329 \\
\hline & & $\mathbf{R}^{2}$ & 0.948 & 0.992 \\
\hline & & $\mathrm{k}_{\mathrm{R}}(\mathrm{L} / \mathrm{g})$ & 341.261 & 343.545 \\
\hline & \multirow[t]{4}{*}{ Redlich-Peterson } & $\alpha_{\mathrm{R}}(\mathrm{L} / \mathrm{mg})$ & 0.325 & 0.238 \\
\hline & & $\beta_{\mathrm{R}}$ & 0.969 & 0.989 \\
\hline & & Ferror & 0.386 & 0.322 \\
\hline & & $\mathbf{R}^{2}$ & 0.9477 & 0.991 \\
\hline & \multirow{4}{*}{$\begin{array}{l}\text { Dubinin- } \\
\text { Radushkevich }\end{array}$} & $Q_{D R}$ & -- & 1419.95 \\
\hline & & $\mathrm{k}_{\mathrm{DR}} \times 10^{+6}\left(\mathrm{~mol}^{2} \mathrm{KJ}^{-2}\right.$ & -- & 1.2 \\
\hline & & $\mathbf{E}(\mathrm{KJ} / \mathrm{mol})$ & -- & \\
\hline & & $\mathbf{R}^{2}$ & -- & 0.988 \\
\hline
\end{tabular}


Table 7: Results of calculations of the various anchoring parameters

\begin{tabular}{|c|c|c|c|c|c|c|c|c|}
\hline & \multicolumn{2}{|c|}{ Model 1} & \multicolumn{4}{|c|}{ Model 2} & \multicolumn{2}{|c|}{ Model 3} \\
\hline & $20^{\circ} \mathrm{C}$ & $30^{\circ} \mathrm{C}$ & & $20^{\circ} \mathrm{C}$ & $30^{\circ} \mathrm{C}$ & & $20^{\circ} \mathrm{C}$ & $30^{\circ} \mathrm{C}$ \\
\hline $\mathbf{n}$ & 1.262 & 1.079 & $\mathbf{n}_{1}$ & 1.775 & 3.553 & $\mathbf{n}$ & 1.26 & 1.078 \\
\hline $\mathrm{Nm}$ & 931.99 & 1392.80 & Nm1 & 548.26 & 101.82 & $\mathrm{Nm}$ & 932.48 & 1392.73 \\
\hline $\mathrm{C}_{1 / 2}$ & 3.3464 & 4.259 & $\mathrm{C}_{1}$ & 2.433 & 1.289 & $\mathrm{C}_{1}$ & 3.347 & 4.259 \\
\hline \multirow[t]{4}{*}{$\mathbf{R}^{2}$} & 0.9778 & 0.9966 & n2 & 1.957 & 1.025 & $\mathrm{C}_{2}$ & 732.22 & 753.18 \\
\hline & & & $\mathrm{Nm}_{2}$ & 173.94 & 1146.87 & $\mathbf{R}^{2}$ & 0.9778 & 0.9966 \\
\hline & & & $\mathrm{C}_{2}$ & 113.86 & 8.326 & & & \\
\hline & & & $\mathbf{R}^{2}$ & 0.9873 & 0.9996 & & & \\
\hline
\end{tabular}

Table 8: the calculation of the thermodynamic parameters

\begin{tabular}{lllll}
\hline Température (K) & Kc (L/g) & $\Delta \boldsymbol{H}^{\mathbf{0}}(\mathbf{k J} / \mathbf{m o l})$. & $\Delta \boldsymbol{S}^{\mathbf{0}}(\mathbf{J} / \mathbf{m o l . K})$ & $\Delta \boldsymbol{G}^{\mathbf{0}}(\mathbf{k J} / \mathbf{m o l})$. \\
\hline 293 & 6.36 & 54.703 & 259.72 & -21.32 \\
303 & 14.60 & & -24.14 \\
313 & 26.65 & & -26.65 \\
\hline
\end{tabular}




\section{Figures Captions}

Figure 1. Chemical structure of the methylene blue.

Figure 2. FT-IR spectrum of the PACK before and after adsorption of BM.

Figure 3. Isoelectric points of PACK $\left(V=50 \mathrm{ml}, \mathrm{T}=25 \pm 2{ }^{\circ} \mathrm{C}\right.$, stirring speed $=250 \mathrm{rpm}, \mathrm{m}_{\mathrm{PACK}}=25$ $\mathrm{mg})$.

Figure 4. SEM captures of PACK

Figure 5. Kinetics data (symbol) of MB adsorption onto PACK and modeling data (lines) by PFO, PSO, and $\mathrm{P}^{\text {nth }} \mathrm{O}$ with different initial concentrations. $\left(\mathrm{V}=200 \mathrm{ml}, \mathrm{T}=25 \pm 2^{\circ} \mathrm{C}\right.$, stirring speed $=250$ $\left.\mathrm{rpm}, \mathrm{m}_{\mathrm{PACK}}=50 \mathrm{mg}\right)$.

Figure 6. Experimental data (points) of MB adsorption onto PACK. Modeling Data (lines) by Langmuir, Freundlich, Sips, and Redlich-Peterson models at different temperatures. (Stirring speed= $250 \mathrm{rpm}, \mathrm{pH}=6.5)$

Figure 7. Simulation of statistical physics models, monolayer single-energy (Model 1), monolayer two-energy (Model 2), and Double-layer two-energy (Model 3).

Figure 8. $\mathrm{pH}$ effect of $\mathrm{MB}$ adsorption onto PACK $\left(\mathrm{V}=50 \mathrm{ml}, \mathrm{T}=25 \pm 2{ }^{\circ} \mathrm{C}\right.$, stirring speed $=250$ rpm, PACK $\left._{\text {P }} 25 \mathrm{mg}\right)$.

Figure 9. The effect of biosorbent dosage on the biosorption of MB onto PACK.

Figure 10 : Recovery percent of various solvent for desorption of MB dye onto PACK. (C 0 $=400 \mathrm{mg} / \mathrm{L}, \mathrm{m}=0.05 \mathrm{~g}$, contact time: $24 \mathrm{~h}$, temperature: $25^{\circ} \mathrm{C}$ ).

Figure 11: Mechanism of interaction MB dye with PACK in aqueous solution 
Figure. 1

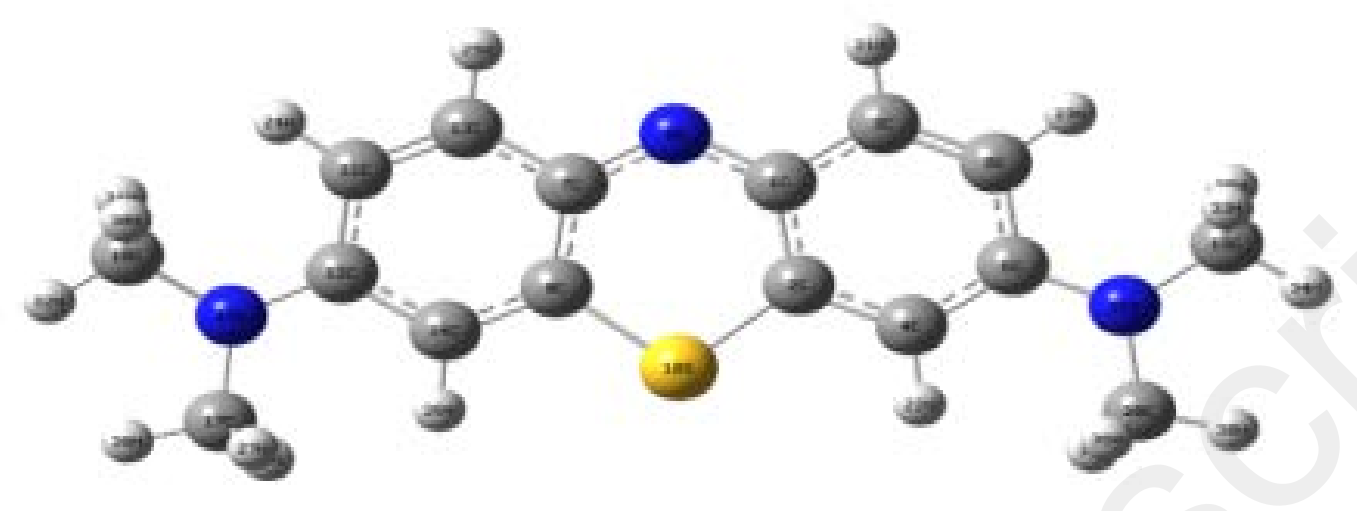

Figure 2

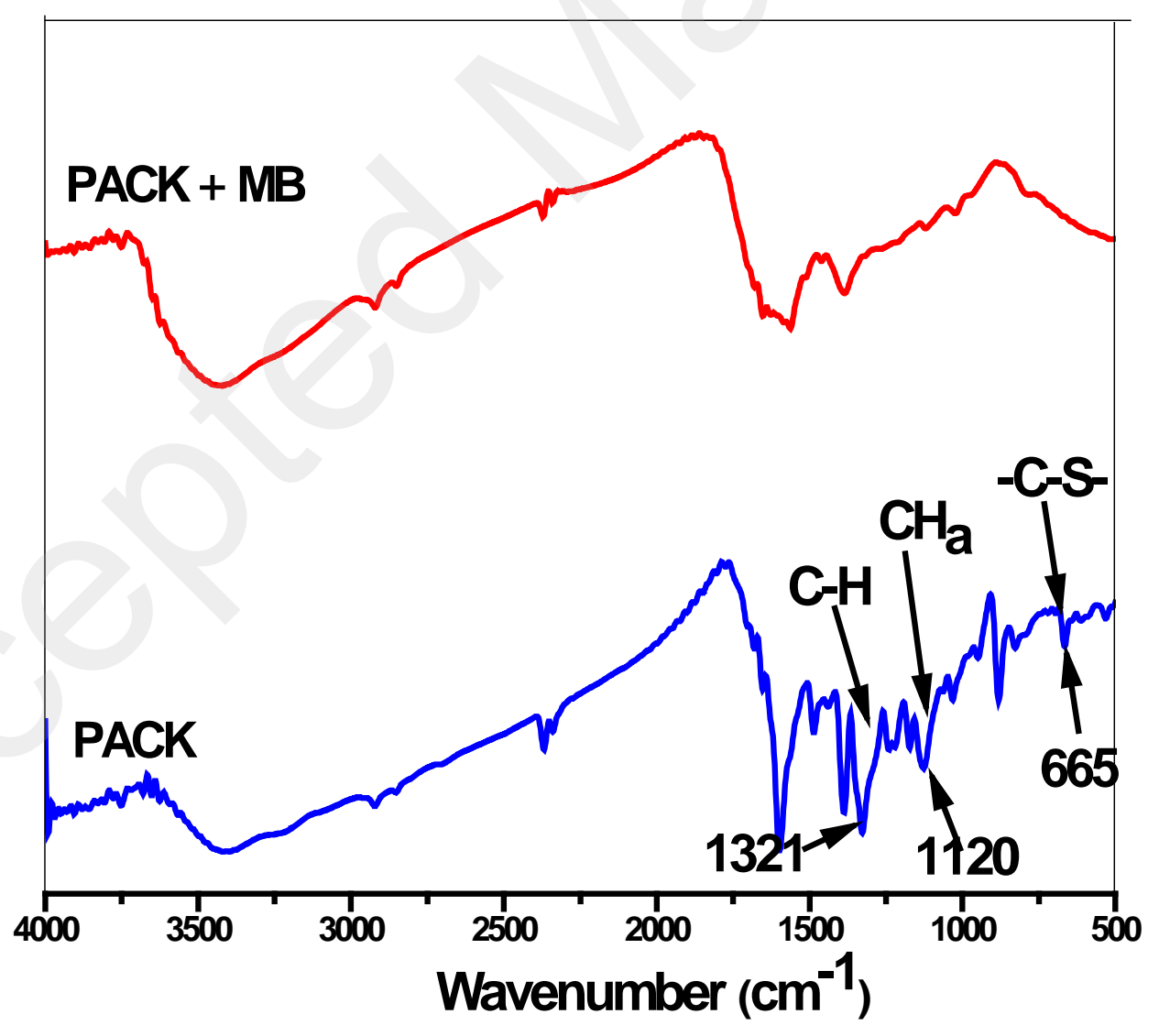


Figure 3

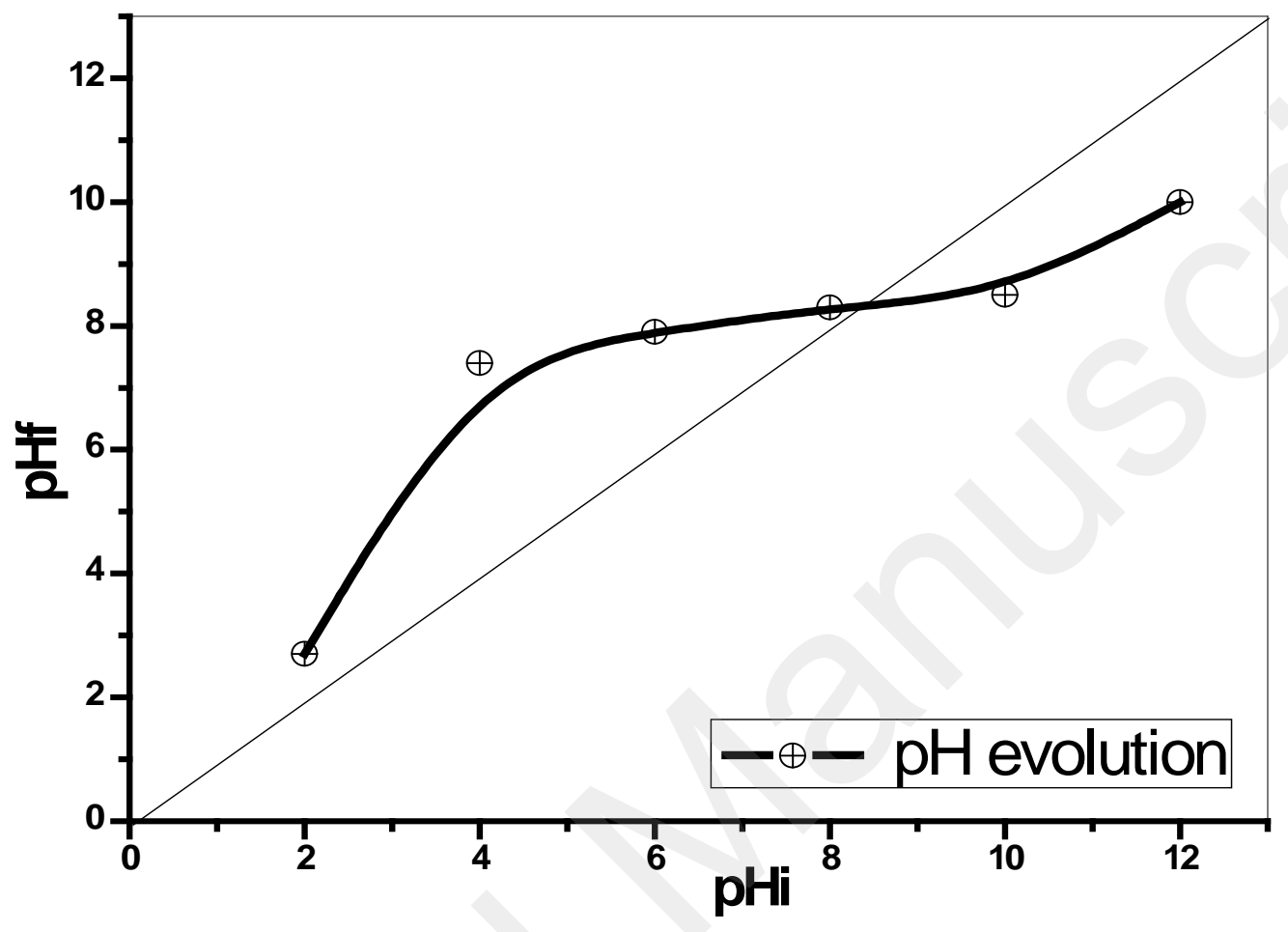

Figure 4

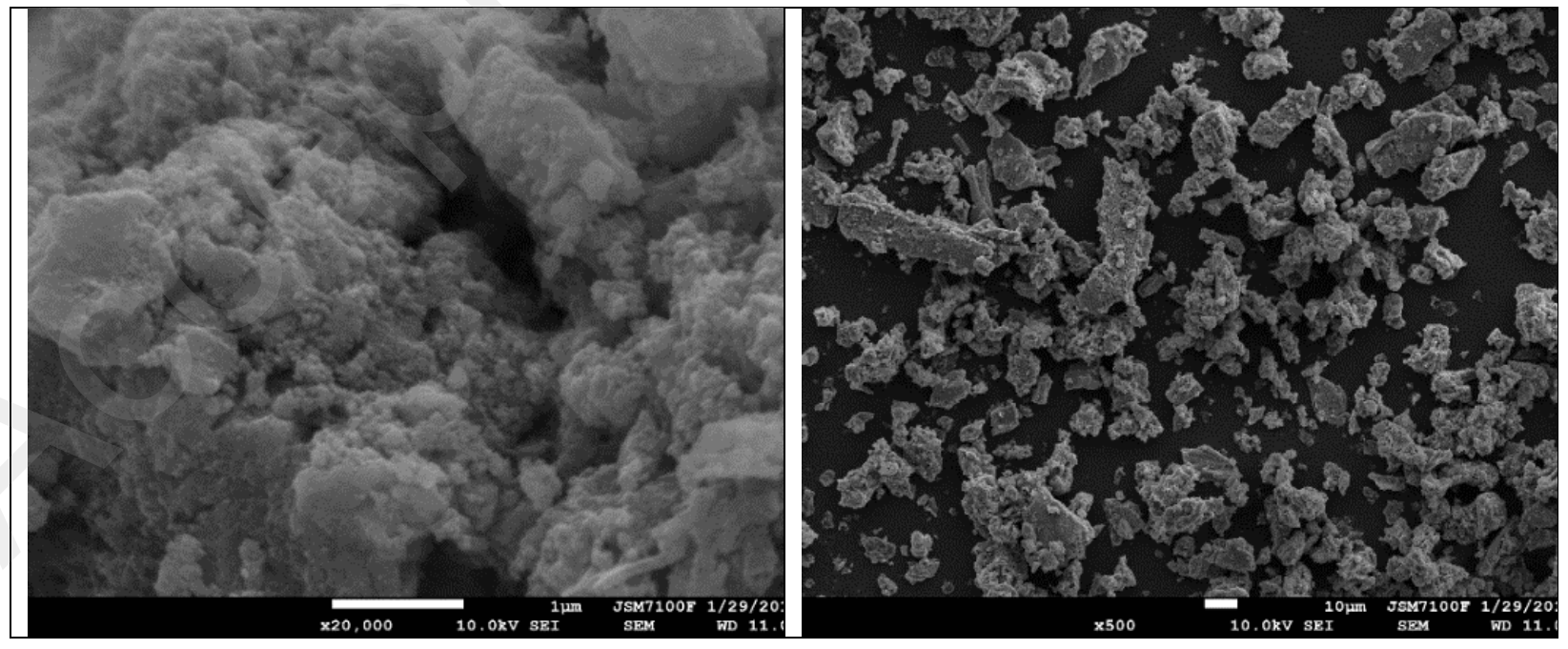


Figure. 5
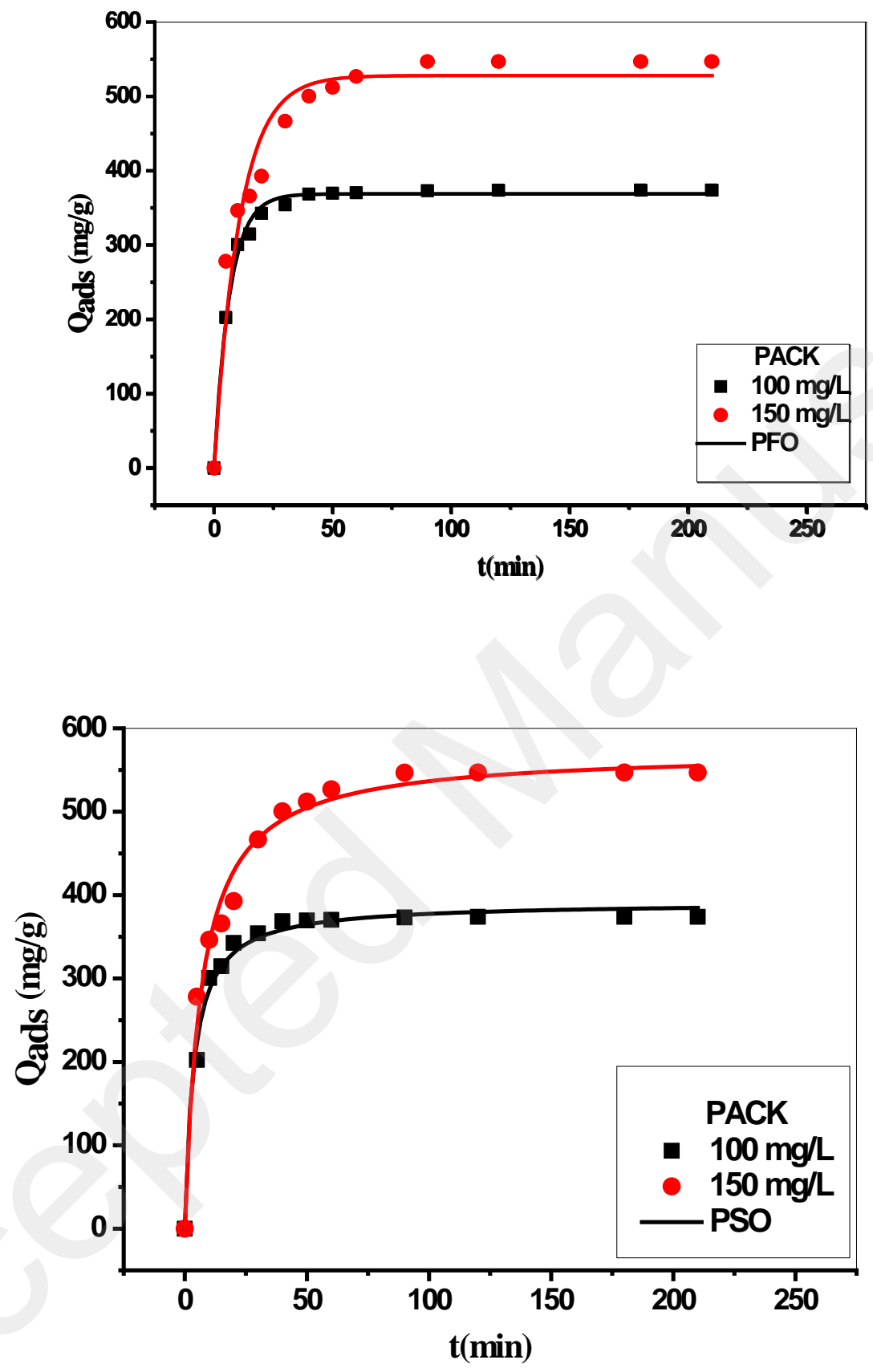


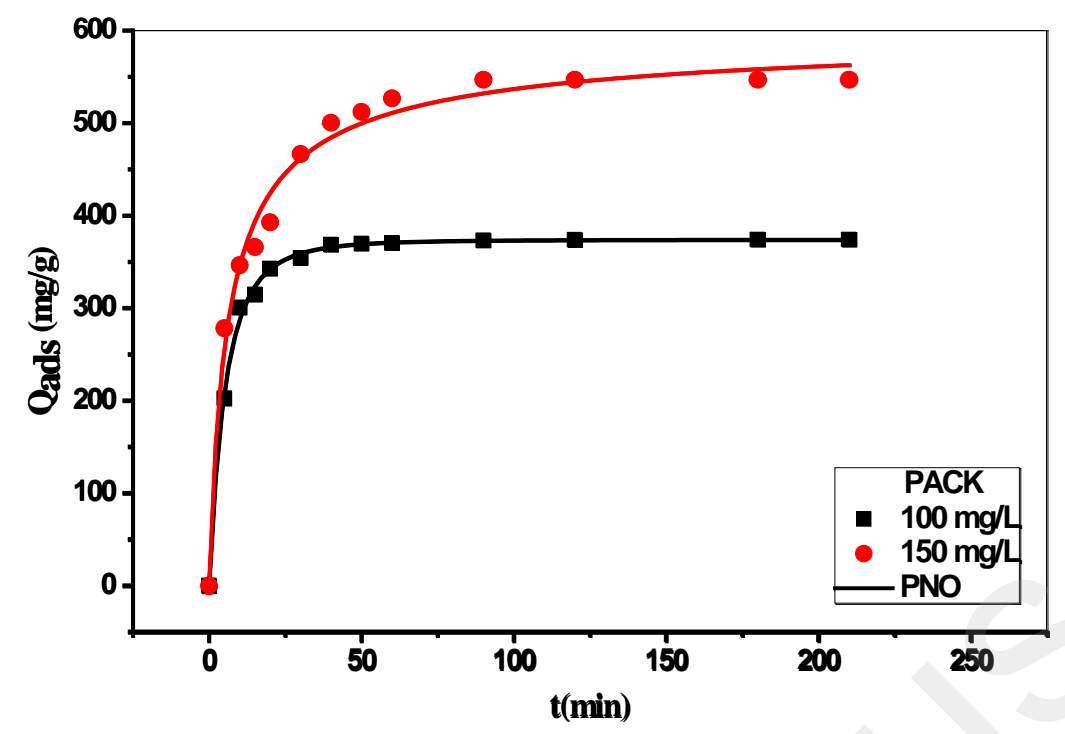

Figure. 6

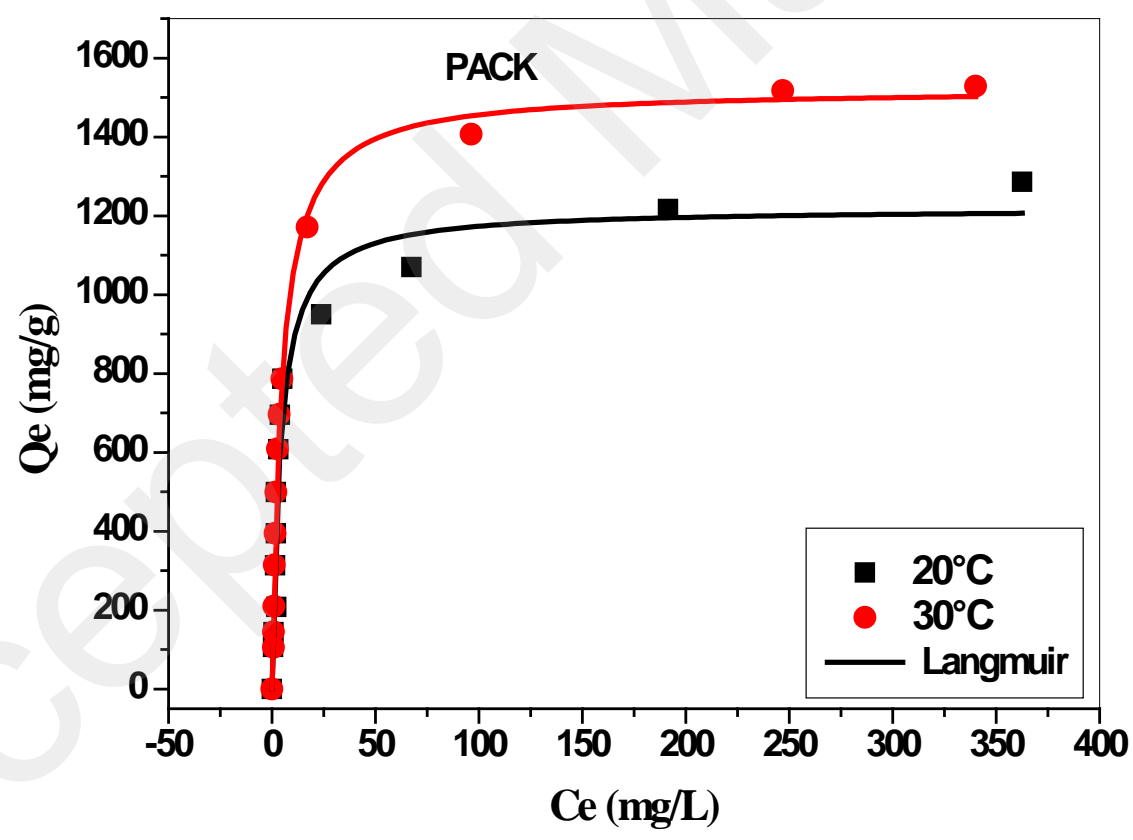



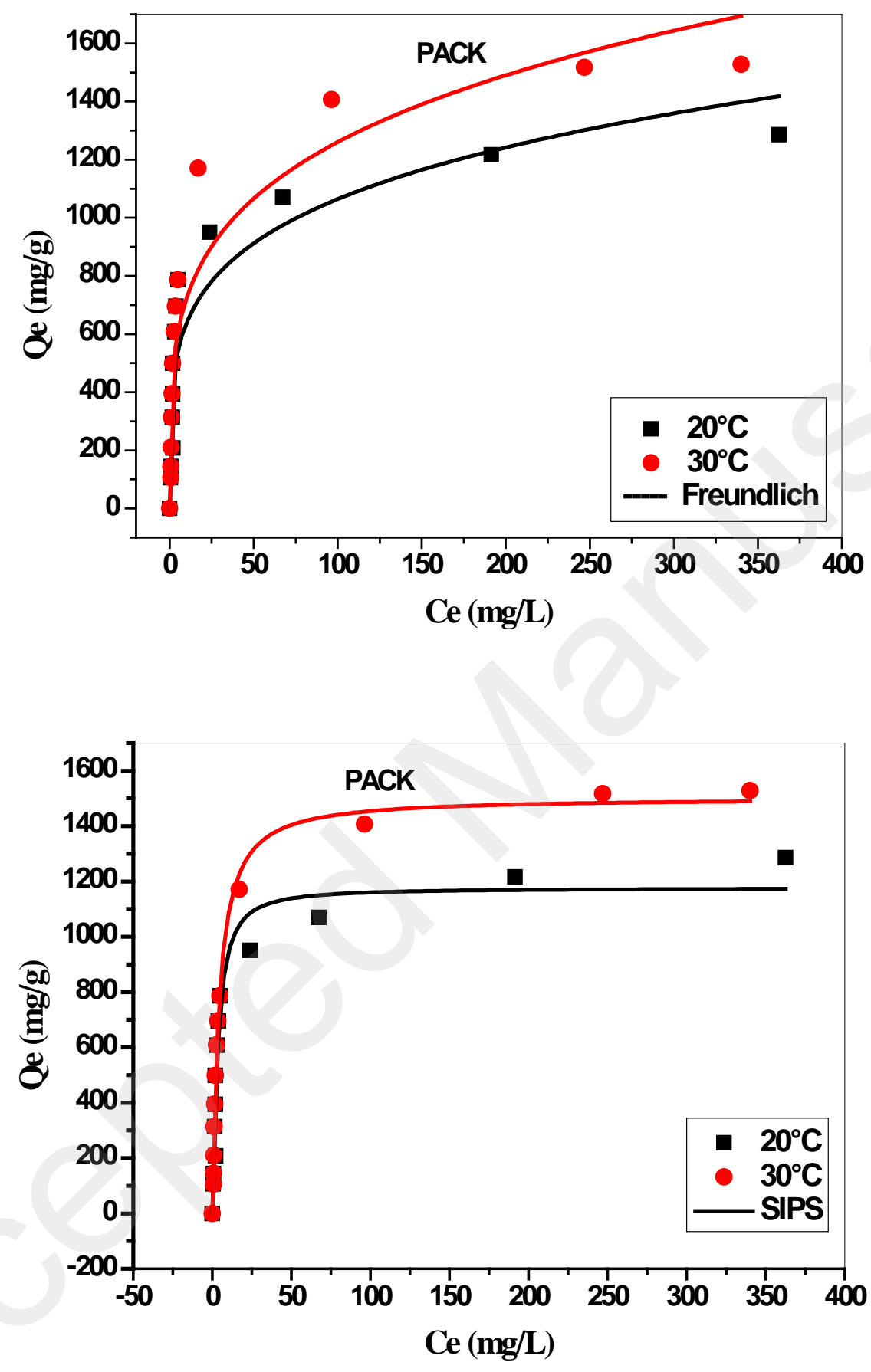

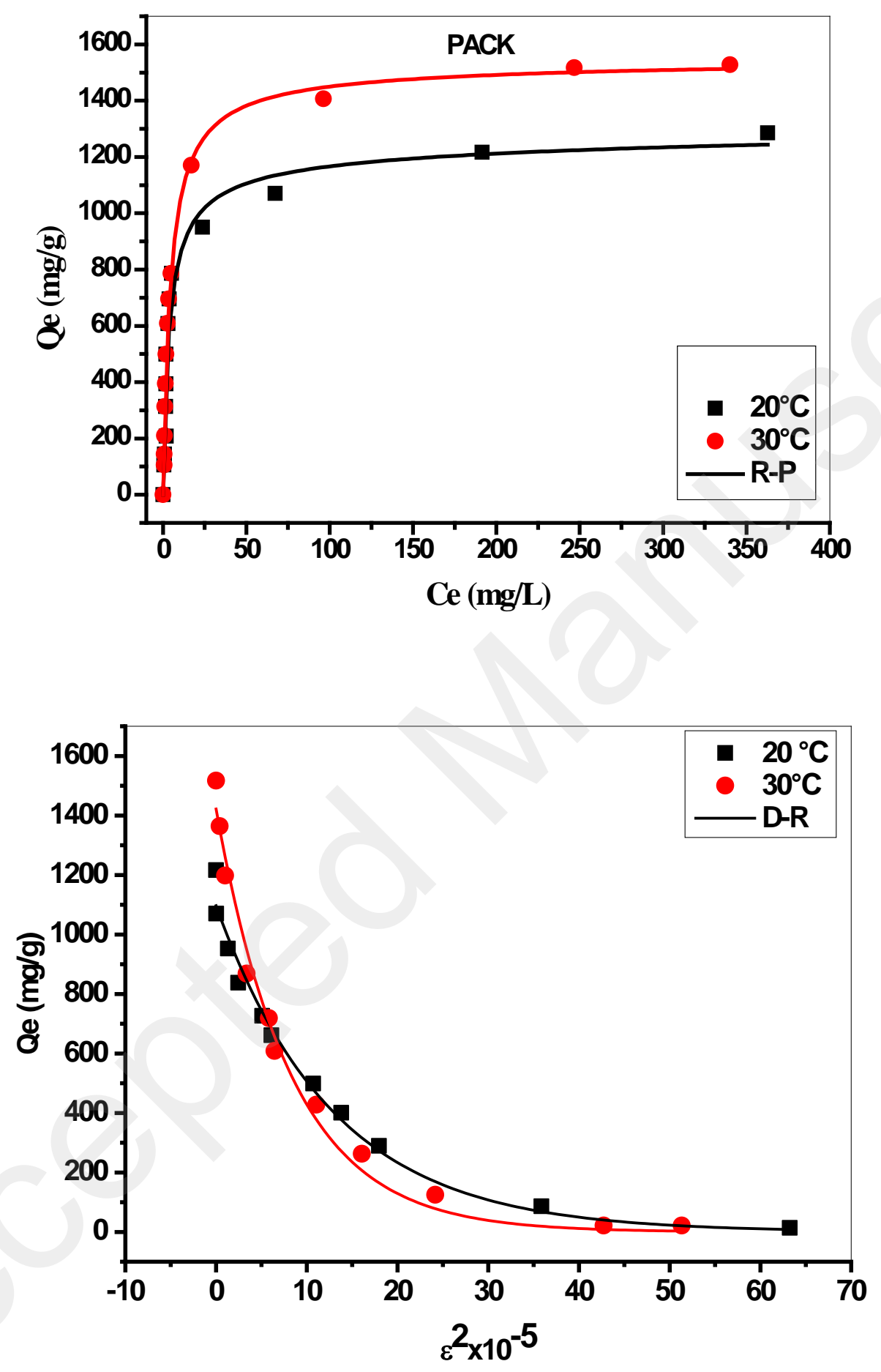
Figure. 7
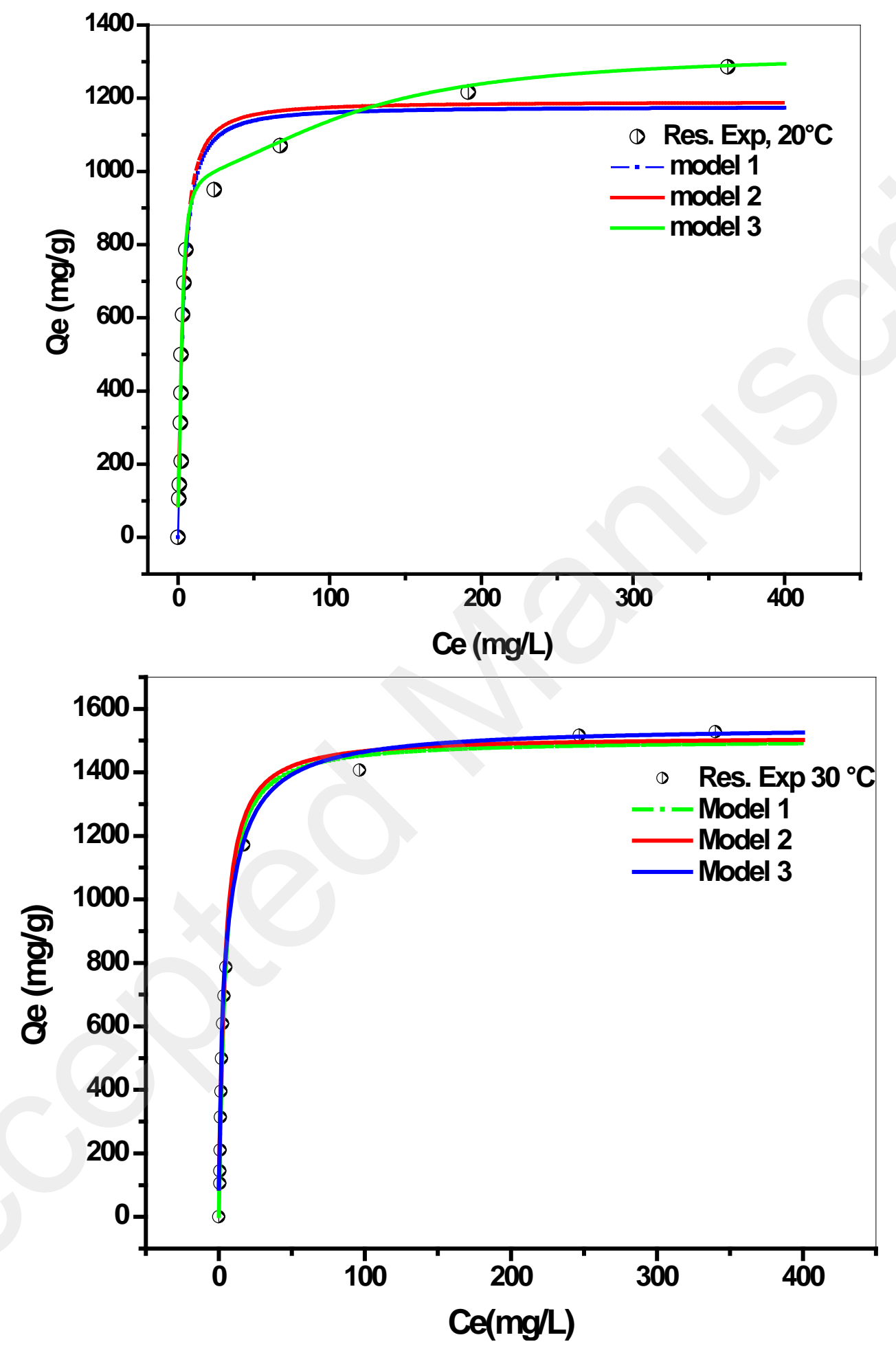
Figure 8

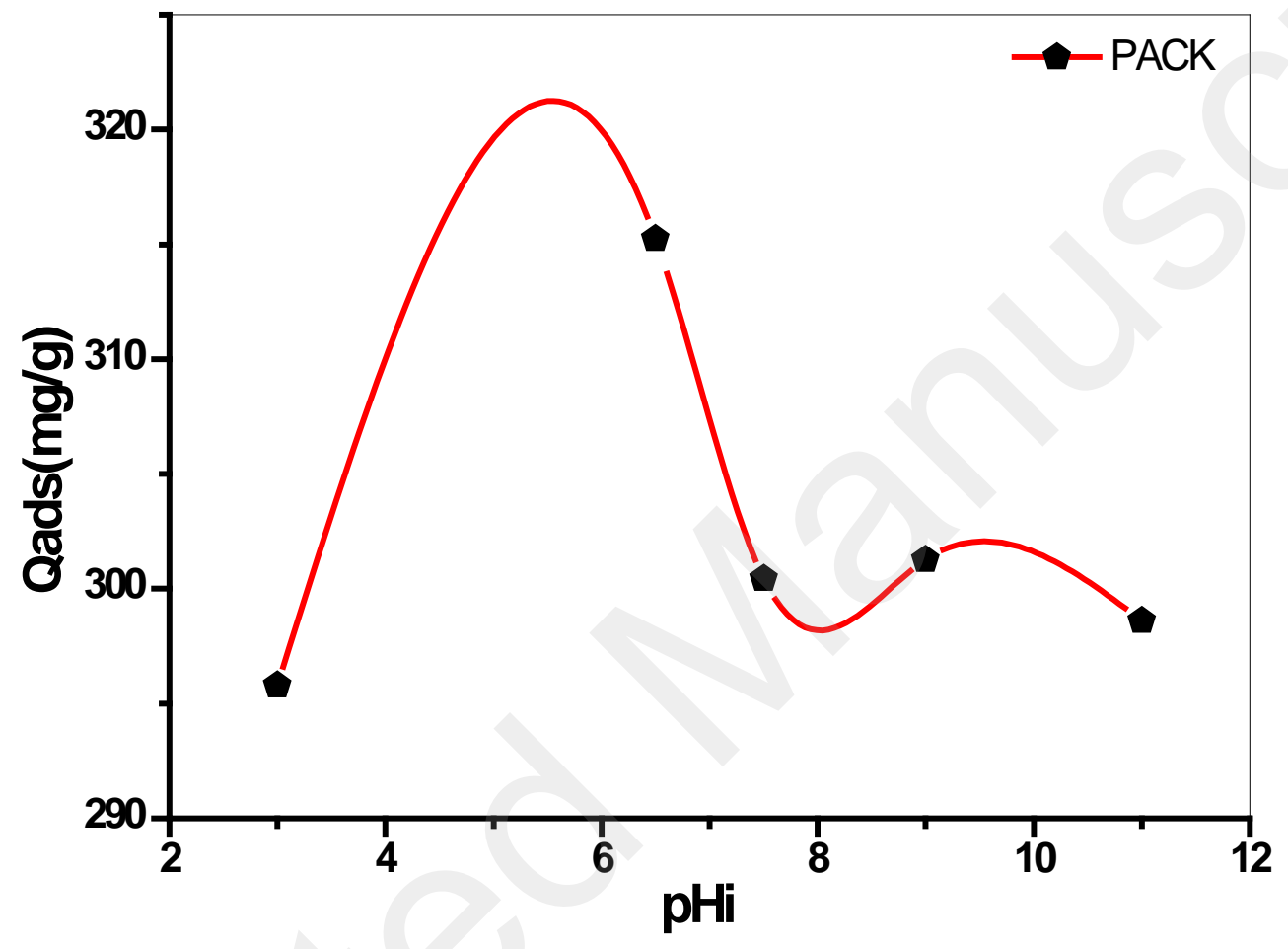


Figure 9

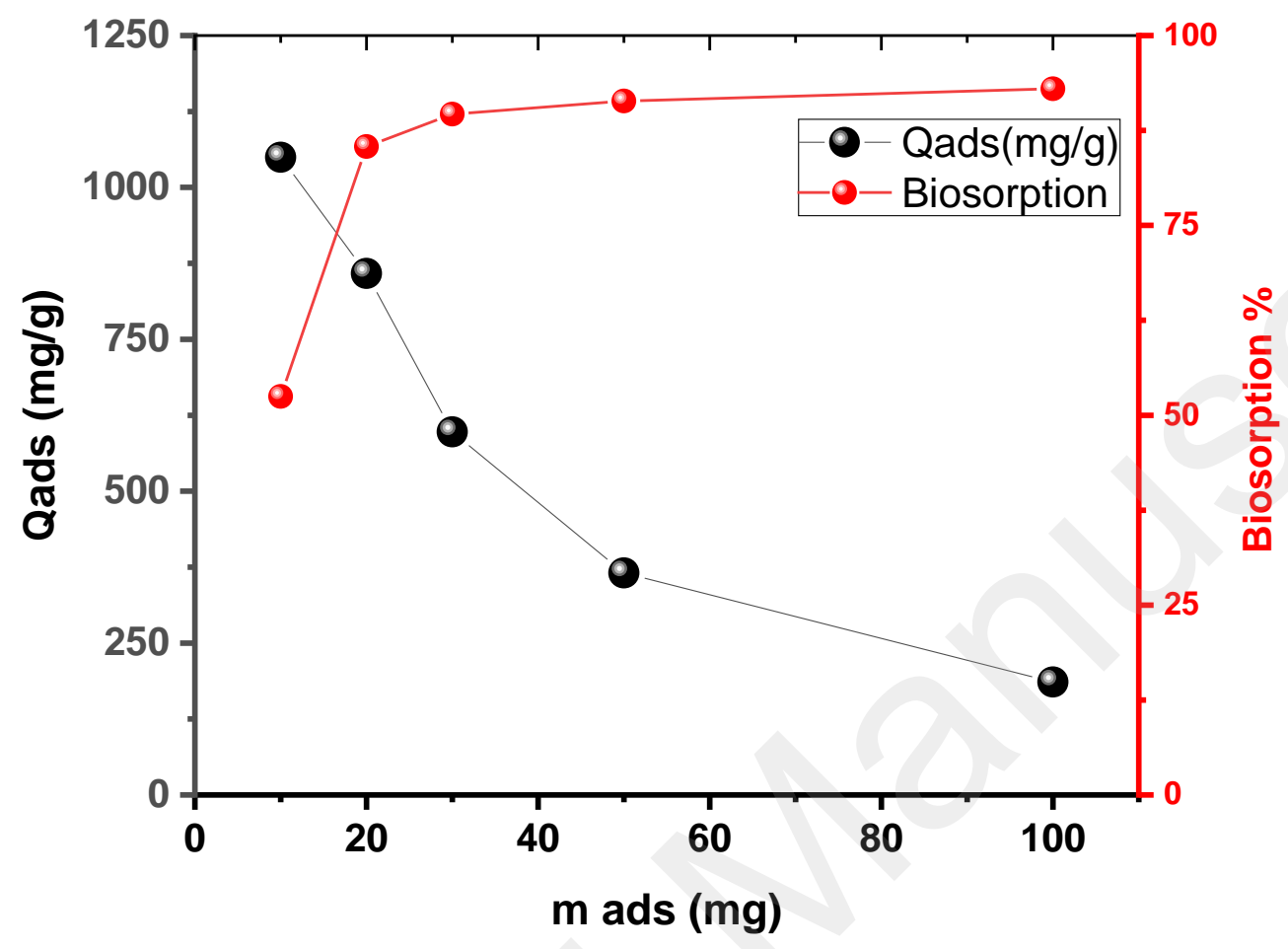


Figure 10

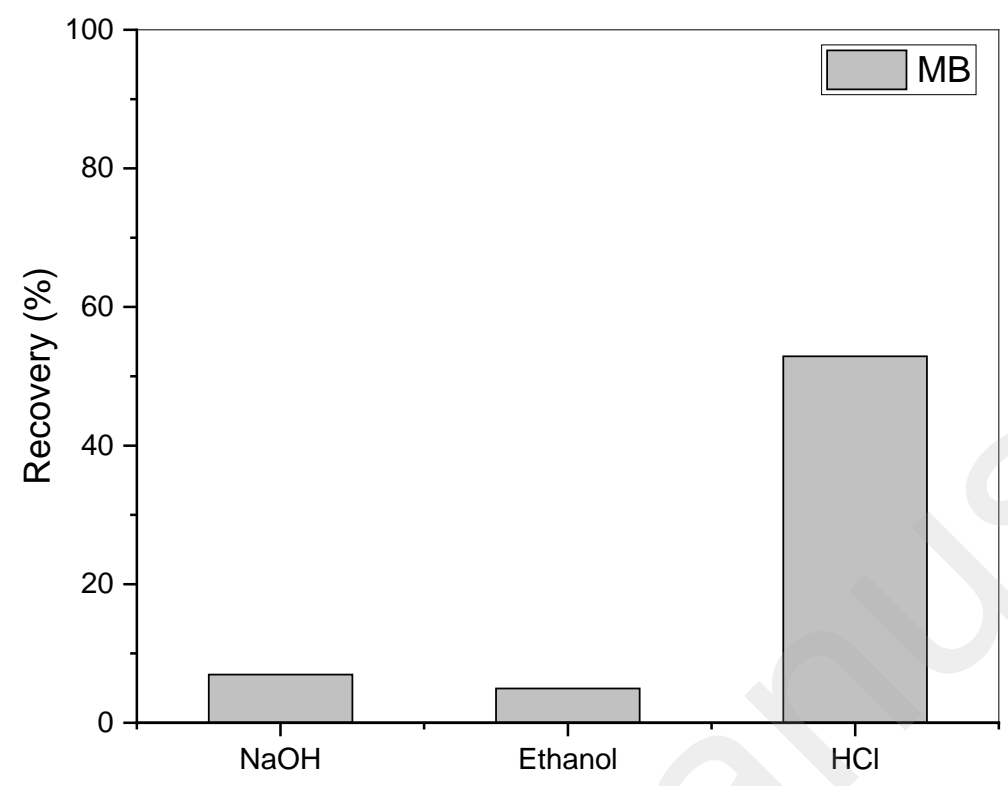

Figure 11

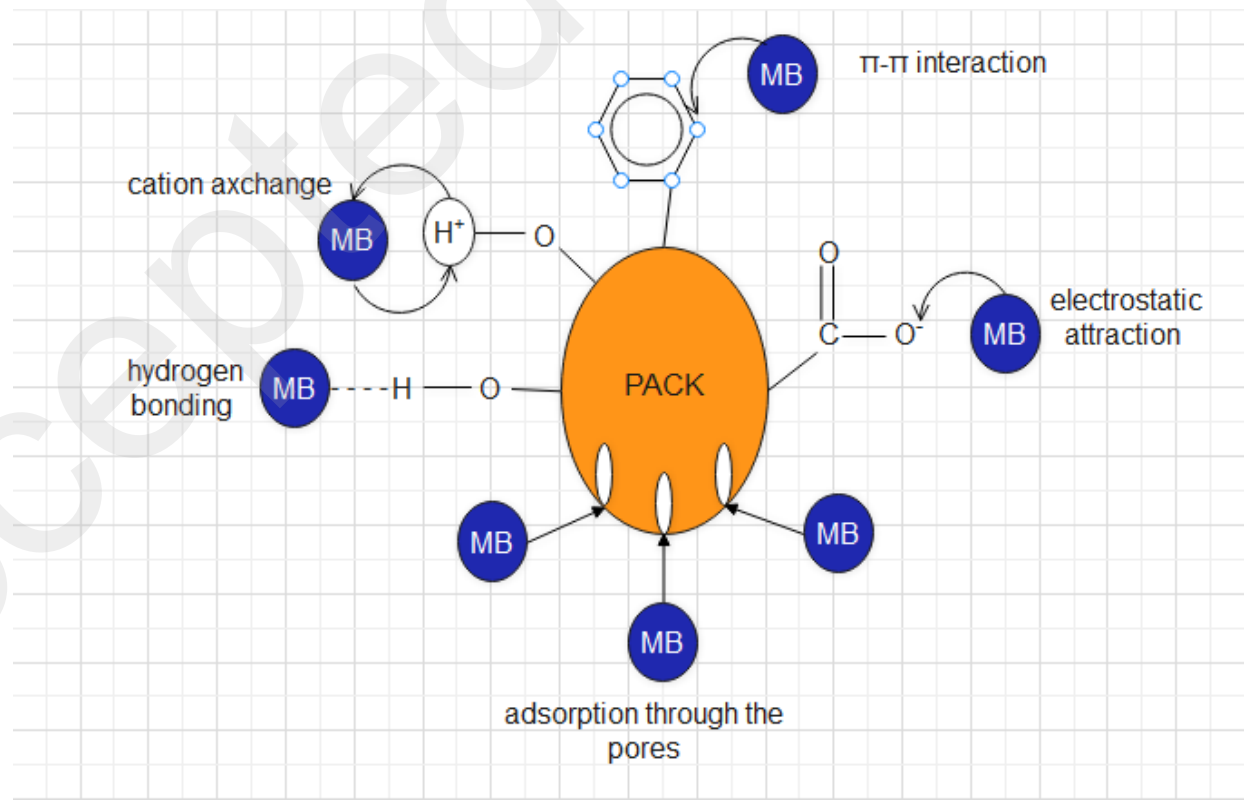

